OPEN ACCESS

Edited by: Ana Cláudia Garcia De Oliveira Duarte, Federal University of São Carlos, Brazil

Reviewed by: Luis Manuel Rama, University of Coimbra, Portugal Jesús Rodríguez Huertas, University of Granada, Spain

*Correspondence: Raphael Fabricio de Souza raphaelctba20@hotmail.com

Specialty section: This article was submitted to Exercise Physiology, a section of the journal

Frontiers in Physiology

Received: 17 December 2021 Accepted: 25 January 2022 Published: 17 February 2022

Citation:

Alves MDdJ, Silva DdS, Pereira EVM, Pereira DD, de Sousa Fernandes MS, Santos DFC, Oliveira DPM,

Vieira-Souza $L M$, Aidar FJ and de Souza RF (2022) Changes in

Cytokines Concentration Following Long-Distance Running: A Systematic Review and Meta-Analysis.

Front. Physiol. 13:838069. doi: 10.3389/fphys.2022.838069

\section{Changes in Cytokines Concentration Following Long-Distance Running: A Systematic Review and Meta-Analysis}

\author{
Micael Deivison de Jesus Alves ${ }^{1,2,3}$, Devisson dos Santos Silva ${ }^{1,2,3}$, \\ Erika Vitoria Moura Pereira ${ }^{1,3}$, Danielle Dutra Pereira ${ }^{4}$, \\ Matheus Santos de Sousa Fernandes ${ }^{5}$, Dayane Franciely Conceição Santos ${ }^{6}$, \\ Davi Pereira Monte Oliveira ${ }^{1}$, Lucio Marques Vieira-Souza ${ }^{2,7}$, Felipe J. Aidar ${ }^{1,2,3}$ and \\ Raphael Fabricio de Souza ${ }^{1,2,3 *}$ \\ ${ }^{1}$ Department of Physical Education, Federal University of Sergipe (UFS), São Cristóvão, Brazil, ${ }^{2}$ Graduate Program in \\ Physical Education, Postgraduate Program in Physical Education, Federal University of Sergipe (UFS), São Cristóvão, Brazil, \\ ${ }^{3}$ Group of Studies and Research of Performance, Sport, Health and Paralympic Sports-GEPEPS, Federal University of \\ Sergipe (UFS), São Cristovão, Brazil, ${ }^{4}$ Department of Physiology and Pharmacology, Biological Sciences Course, Federal \\ University of Piauí, Teresina, Brazil, ${ }^{5}$ Graduate Program, Postgraduate Program in Neuropsychiatry and Behavioral Sciences, \\ Federal University of Pernambuco (UFPE), Recife, Brazil, ${ }^{6}$ Department of Nutrition, Federal University of Sergipe (UFS), São \\ Cristóvão, Brazil, ${ }^{7}$ Physical Education Course, State University of Minas Gerais-UEMG, Passos, Brazil
}

Long-distance running is an exhausting effort for the whole organism. Prolonged aerobic exercise induces changes in inflammatory markers. However, predicting muscle damage in response has limitations in terms of selecting biomarkers used to measure inflammatory status. The present study conducts a systematic review and meta-analysis of articles focusing in ultra-marathon, marathon, and half-marathon and levels of cytokines. The search was conducted in PubMed, Web of Science, and Scopus databases, resulting in the inclusion of 76 articles. IL-6 was highlighted, evaluated in 62 studies and show increase in the standard mean difference (SMD): half-marathon (SMD -1.36; IC 95\%: - 1.82, -0.89, $\mathrm{Ch}^{2}: 0.58$; tau ${ }^{2}: 0.00 ; p<0.0001$ ), marathon (SMD -6.81; IC 95\%: -9.26, -4.37; $\left.\mathrm{Ch}^{2}: 481.37 \mathrm{tau}^{2}: 11.88 ; p<0.0001\right)$ and ultra-marathon (SMD -8.00 IC 95\%: -10.47, -5.53; $\mathrm{Ch}^{2}: 328.40 ;$ tau $\left.^{2}: 14.19 ; p<0.0001\right)$. In contrast meta-regression analysis did not show relationship to the running distance $(p=0.864)$. The meta-analysis evidenced increase in the concentration of IL-1ra $(p<0.0001)$, IL-1B $(p<0.0001)$, IL-8 $(p<0.0001), I L-10(p<0.0001)$ and TNF- $\alpha(p<0.0001)$. Reduction in $\mathrm{IL}-2(p<0.0001)$ and INF-y $(p<0.03)$ and no change in the IL-4 $(p<0.56)$. The number of studies evaluating the effect of adipokines was limited, however Leptin and Resistin were recurrent. The effects of an acute bout of prolonged aerobic exercise will protect against chronic systemic inflammation. The time to return to baseline values showed a substantial and dose-dependent relationship with run volume. The concentration of IL-6 was robustly studied and the marathon running was the most explored. Network of endocrine interactions in which circulating factors, released in extreme exercises, 
interplay through inter-organ crosstalk and physiologic changes were expressed. The running volume variability was able to modulate compounds that play a fundamental role in the maintenance of homeostasis and cell signaling.

Keywords: marathon, aerobic, endurance, cytokine, myokine, adipokine

\section{INTRODUCTION}

Regular physical activity has been described as positive on protein and enzyme concentration, increases in insulin sensitivity, skeletal muscle glucose uptake (Turcotte and Fisher, 2008) and also for promoting a generalized anti-inflammatory state (Gleeson et al., 2011). In contrast, some negative effects are evidenced after complex competitions, resulting from the high volume and repeated physical efforts as occurs in ultramarathons ( $>6 \mathrm{~h}$ of duration or $>50 \mathrm{~km}$ ) (Knechtle and Nikolaidis, 2018). These specific runs require great resistance and muscle contraction, resulting in microtraumas to the connective tissue, bone, and skeletal muscle with exercise-induced muscle damage (EIMD) (Smith, 2000; Suzuki et al., 2003; Järvinen et al., 2013).

The EIMD is related to the inflammatory response, characterized by the body's defense against an aggressor agent, whose objective is to promote repair of the damaged tissue (Cerqueira et al., 2020). The magnitude of this process is regulated by pro (about $1.5-24 \mathrm{~h}$ after exercise) and anti-inflammatory factors (from 24 to $72 \mathrm{~h}$ after exercise) (Zaldivar et al., 2006; Allen et al., 2015; Cerqueira et al., 2020), with cytokines being responsible for coordination, amplification, regulation of the magnitude, duration, and effect of inflammatory events (Moldoveanu et al., 2001). Cytokines are molecules produced by cells of the immune system, active musculature, and other tissues such as adipose tissue (de Oliveira dos Santos et al., 2021). In addition to an important modulating activity of inflammation, they regulate the activation of energy pathways that support this process (Petersen and Pedersen, 2005).

Adipose and skeletal muscle and tissue are the main endocrine organs that produce adipokines and myokines. These biomarkers can be detrimental or beneficial in the body and crosstalk between different tissues (Leal et al., 2018) acting on the endocrine, paracrine and autocrine pathways (de Oliveira dos Santos et al., 2021). Knowledge about the loss of cytokine homeostasis brings to light a better understanding of the metabolic disorders resulting from long-term running, resulting to marked changes in the concentration profile, which can be the basis of many physiological and pathophysiological disorders (Knechtle and Nikolaidis, 2018), questioning the real health benefit. These questions are relevant not only in ultra-marathons, but also in less volumes (i.e., marathons and half-marathons) (Suzuki et al., 2003; Kaufmann et al., 2021; Tanner et al., 2021).

Under normal conditions cytokines lead to a systemic anti-inflammatory state (Gomarasca et al., 2020). Becoming potentially permissive for optimizing body energy expenditure (Pedersen, 2019; Das et al., 2020) and for the protection of diseases associated with inflammation, insulin resistance and hyperlipidemia. On the other hand, alarming results are shown when exercise is performed in large volumes, a dramatic increase in interleukin (IL)-6 concentration is observed (Margeli et al., 2005), a decrease in the concentration of myostatin mRNA in the skeletal muscle (Allen et al., 2011), consistent acute tissue inflammatory lesion (Margeli et al., 2005; Papassotiriou et al., 2008; Goussetis et al., 2009) and EIMD (Suzuki et al., 2003). That is, indicators of the potentially more injurious condition in prolonged exercise (Kerschan-Schindl et al., 2009).

Understanding that broadening the discussion of this information is of great importance for sport physiologists, coaches and athletes, which show an increase in the number of practitioners and popularity. In this systematic review followed by a meta-analysis, we sought to verify the current state of investigation in relation to the effects of long-term running on cytokine concentration.

\section{METHODS}

\section{Search Strategy}

The systematic review report was carried out based on the "Preferred Reporting Items for Systematic Reviews and MetaAnalyses statement" (PRISMA) (Page et al., 2021). A research was performed in the PubMed, Web of Science and Scopus databases, from September 1 to 13, 2021, using the following boolean operators (AND/OR) and terms: "marathon" OR "aerobic" OR "endurance" AND "cytokine" OR "myokine" OR "adipokine", as well as the use of synonyms and related search terms, with no start date limit and, considering as the final year, the year 2021. The strategy of seeking additional articles in the gray literature and in the references of the papers found were adopted, with the aim of expanding the results.

Search results loaded into the online bibliographic management software Rayyan ${ }^{\mathrm{TM}}$. After excluding duplicates, all titles and abstracts were independently analyzed by two investigators to determine the study's eligibility for inclusion in the review, in case of divergence a third author was consulted to establish a consensus. After these initial steps, the full texts were evaluated and the name of the first author, year of publication, title, objective, running distance, sample, runner's level, age, type of collection and inflammatory markers (pre, immediately after, after 24,48 , and $72 \mathrm{~h}$ ).

\section{Eligibility Criteria Abstract Selection}

During the process of reading titles and abstracts, the following inclusion criteria were adopted: (I) studies involving running with distances equal to or $>21 \mathrm{~km}$ and (II) measurement of pre and post-running inflammatory biomarkers. 


\section{Full-Text Articles Selection}

As a second selection step, the studies were excluded for the following reasons: (1) pre-running collections with periods $>7$ days, (2) post-running with only periods $>24 \mathrm{~h}$, (3) jobs that showed running on a treadmill, (4) ingestion of drug, supplement or performance-maximizing drink, (5) runners with some pathology and (6) another sporting activity added to running. All parameters were evaluated in blood, urine, nasal and sputum samples collected before and after running.

\section{Risk of Bias Assessment}

The recommendations of the Cochrane risk of bias assessment tool were followed, adopting the risk of bias strategy (Table 1) by two authors independently, and a third author was consulted to define the differences (Higgins et al., 2011) and the Review Manager program (RevMan5.3), developed for Systematic Reviews, which is available for free download (https://training. cochrane.org/online-learning/core-software-cochrane-reviews/ revman/revman-5-download).

\section{Statistical Analysis}

The results were expressed as the standard mean difference (SMD) of the $95 \%$ confidence intervals (CI) presented by the Forest plot graph. For the analysis, 2 conditions were used: pre and post running. The studies that evaluated IL- 6 were combined for trials with parameters (half-marathon, marathon, and ultramarathon). To identify if the variables ultra-marathon, marathon and half-marathon could be significantly associated with effect size differences, a meta-regression analysis was performed. For studies with more than one intervention group, we considered only the control or placebo group without drug administration or other interventions. We used Cochran's $\left(\mathrm{Ch}^{2}\right)$ and tau-square test $\left(\operatorname{tau}^{2}\right)$ to assess heterogeneity. The $I^{2}$ statistic was used to assess inconsistency (the percentage of the total variation of heterogeneity) of the effects of exercise (Higgins et al., 2003). We assessed visually and objectively the propagation of the risk of bias the symmetry graphically using funnel plots. The threshold for statistical significance was set to $\mathrm{p}<0.05$.

\section{RESULTS}

\section{Search Results}

In the initial search, 5,528 articles were found, and 2,372 duplicate articles were excluded. Of 3,156 articles screened for eligibility, 3,061 were excluded based on title or abstract. The full texts of 95 potentially eligible studies were evaluated. Of these, 76 met the criteria and were included in the review, among which 29 made up the meta-analyses (Figure 1).

\section{Risk of Bias of Included Studies}

Of the 29 studies included, at least 10 studies were at risk of bias. Four studies had a high risk of random sequence generation and allocation concealment. Ten studies showed risk in blinding participants and researchers. When the blinding of results and selective notification was evaluated, two studies presented a risk. All studies had a low risk for incomplete outcome data. No study presented the risk of other biases (Figures 2, 3).

\section{Running Characteristic}

Table 2 summarizes the results obtained from the 76 studies that investigated the relation to the degree of running volume in studies that evaluated cytokines in ultra-marathon, marathon, and half-marathon competitions. It was identified that the marathon had the highest proportion of articles investigated $39 / 76$, followed by running of ultra-marathon $21 / 76$ and halfmarathon 9/76, four studies evaluated marathon and halfmarathon (Bonsignore et al., 2002; Reihmane et al., 2013; Niemelä et al., 2016; Bekos et al., 2019), furthermore 2/76 evaluated the distance of $35 \mathrm{~km}$ (Miles et al., 2006; Yargic et al., 2019) and the study of Skinner et al. (2021) evaluated two runs 40 e $171 \mathrm{~km}$.

From the articles that evaluated ultra-marathon running, four studies (Drenth et al., 1995; Donnikov et al., 2009; Gill et al., 2015a; Benedetti et al., 2021) evaluated distances in the ranges of $51-86,51-81,122-208$, and $99-218 \mathrm{~km}$ respectively, two studies (Mastaloudis et al., 2004; Díaz-Castro et al., 2012) $50 \mathrm{~km}$ distance, one study (Sansoni et al., 2017) $65 \mathrm{~km}$ distance, one study (Nieman et al., 2002) $80 \mathrm{~km}$ distance, one study (Peters et al., 2001) $90 \mathrm{~km}$ distance, four studies (Chiu et al., 2013; Czajkowska et al., 2020; Kasprowicz et al., 2020; Wołyniec et al., 2020) evaluated $100 \mathrm{~km}$, four studies (Nieman et al., 2003, 2005, 2006, 2007) evaluated $160 \mathrm{~km}$, one study (Roupas et al., 2013) evaluated $180 \mathrm{~km}$, one study (Kim et al., 2007) evaluated $200 \mathrm{~km}$, one study (Gill et al., 2015b) evaluated $230 \mathrm{~km}$ and one study (Shin and Lee, 2013) evaluated $308 \mathrm{~km}$. Some studies that evaluated the ultra-marathons presented particularities in relation to the topography characteristic. Four studies were carried out in mountains with uphill (5.500 meters) and dowhill (6.500 meters) (Nieman et al., 2003, 2005, 2006 and Nieman et al., 2007). Three studies reported parts with uphill by 2,800 meters (Díaz-Castro et al., 2012); 4,000 meters (Sansoni et al., 2017) and 10000 meters (Skinner et al., 2021). Four studies on trails with the varying ground (Mastaloudis et al., 2004; Roupas et al., 2013; Gill et al., 2015a,b). Five studies with flat ground, including athletics tracks (Chiu et al., 2013; Czajkowska et al., 2020; Kasprowicz et al., 2020; Wołyniec et al., 2020; Benedetti et al., 2021), the other studies did not identify the running ground.

\section{Runner's Level and Sex}

Experienced runners, athletes, trained and well-trained were evaluated in 22 studies (Niess et al., 1999; Fehrenbach et al., 2000; Ostrowski et al., 2000; Suzuki et al., 2000, 2003; Toft et al., 2000; Bonsignore et al., 2002; Zaccaria et al., 2002; Nieman et al., 2003, 2005, 2006, 2007; Cox et al., 2010; Abbasi et al., 2013; Chiu et al., 2013; Roupas et al., 2013; Santos et al., 2013b; Shanely et al., 2014; Bachi et al., 2015; Sansoni et al., 2017; Passos et al., 2019; Gaggini et al., 2021). Amateur, recreational runners were present in 13 studies (Drenth et al., 1995; Castell et al., 1996; Starkie et al., 2001; Bonsignore et al., 2002; Kim et al., 2007; Díaz-Castro et al., 2012; Vaisberg et al., 2012, 2013; Reihmane et al., 2013; Vuolteenaho et al., 2014; Luna Junior et al., 2016; dos Santos et al., 2020; Sliwicka et al., 2021). Other characteristics such as experience ranging from 1 to 16 years, finalists, and time in a marathon running of $<5 \mathrm{~h}$ were adopted in three studies 
TABLE 1 | Risk of bias evaluation of included studies.

\begin{tabular}{|c|c|c|}
\hline Bias domain & Source of bias & Support judgment \\
\hline \multirow[t]{2}{*}{ Selection bias } & Random sequence generation & $\begin{array}{l}\text { The method used to generate the allocation sequence had sufficient detail to allow an evaluation and } \\
\text { produce comparable groups }\end{array}$ \\
\hline & Allocation concealment & $\begin{array}{l}\text { The method used to conceal the allocation sequence, or detailing the intervention allocations could have } \\
\text { been predicted }\end{array}$ \\
\hline Bias performance & Blindness of participants & There was blind trial for participants and researchers \\
\hline Bias detection & Result evaluation blindness & The measures used for the evaluation of results were blind \\
\hline Frequency of friction & Incomplete results data & The conclusion of the results presented exclusions of analyzes or any other friction \\
\hline Report Bias & Selective reports & How the selective results report was examined and what was found \\
\hline Another type of bias & Anything else, ideally pre-specified & Important concerns about bias not covered in the other domains in the tool \\
\hline
\end{tabular}

respectively (Uchakin et al., 2003; Pugh et al., 2019; Wołyniec et al., 2020). The other studies did not presented the levels of the evaluated runners. Women were present in $35 \%$ of the studies. However, only the study by Abbasi et al. (2013) broken down the results by sex.

\section{Running Time}

Mean running conclusion times were reported in $68 \%$ of the studies. In the half-marathon, the mean times varied between 1:30 and 2:12 h (Zaccaria et al., 2002; Ng et al., 2008; Cox et al., 2010; Abbasi et al., 2013; Reihmane et al., 2013; Niemelä et al., 2016; Costello et al., 2020; Gaggini et al., 2021). In marathons the mean times varied between 2:52 and 4:41 h (Castell et al., 1996; Toft et al., 2000; Pistilli et al., 2002; Henson et al., 2004; Howatson et al., 2010; Scherr et al., 2011, 2012; Nickel et al., 2012; Bernecker et al., 2013; Reihmane et al., 2013; Santos et al., 2013a,b; Vaisberg et al., 2013; Shanely et al., 2014; Vuolteenaho et al., 2014; Wilhelm et al., 2014; Niemelä et al., 2016; Clifford et al., 2017; Passos et al., 2019; Pugh et al., 2019; Sierra et al., 2019a; Batatinha et al., 2020; dos Santos et al., 2020; Larsen et al., 2020; Sliwicka et al., 2021; Tavares-Silva et al., 2021). In ultra-marathons, the mean times ranged between 6:00 and 62:20 h (Drenth et al., 1995; Peters et al., 2001; Nieman et al., 2002, 2003, 2005, 2006, 2007; Zaccaria et al., 2002; Mastaloudis et al., 2004; Kim et al., 2007; Donnikov et al., 2009; Chiu et al., 2013; Shin and Lee, 2013; Gill et al., 2015a; Czajkowska et al., 2020; Wołyniec et al., 2020; Benedetti et al., 2021; Skinner et al., 2021), with distances of 51-308 km. Three studies evaluated the specific distances of $35,35.2$ and $40 \mathrm{~km}$, with the following mean conclusion times 5:08 (Yargic et al., 2019), 6:10 (Miles et al., 2006) and 6:50 hours (Skinner et al., 2021) respectively.

\section{Effects of Long-Distance Running on Cytokine Concentration}

The effects of long-distance running on cytokine concentration were evaluated in 76 studies. The analyzed results comprised a period of up to $72 \mathrm{~h}$ after the running. The concentration of 35 cytokines was identified (IL-6, IL-8, IL-1 $\beta$, IL-1ra, IL-2, IL-4, IL-10, IL-12, IL-12p40, IL-12p70, IL-23, IL-33, IL-15, IL-7, IL-17a, IL-3, IL-5, Tumor Necrosis Factor-Alfa (TNF- $\alpha$ ), Interferon Gamma (IFN- $\gamma$ ), Granulocyte ColonyStimulating Factor (VEGF-A), Fractalkine, Leptin, Resistin, Adiponectin, Visfatin, Tumor Necrosis Factor Type II p75
(sTNFRII), Interleukin-6 Receptor gp80 (sIL-6R), Transforming Growth Factor-Beta (TGF- $\beta$ ), Granulocyte-Macrophage Colony-Stimulating Factor (GM-CSF), Granulocyte ColonyStimulating Factor (G-CSF), Monocyte Chemotactic Protein 1 (MCP-1), Macrophage Inflammatory Protein 1 Beta (MIP$1 \beta)$, Heat Shock Protein (HSP)-72, HSP27 and HPS70). The review shows that long-term runs can change the volume of cytokine concentration, presenting as relevant factors the distance of the run and the recovery time until the analysis (Table 2).

\section{Interleukin 6}

The most evaluated cytokine was IL- 6 found in 62 studies (Drenth et al., 1995; Castell et al., 1996; Ostrowski et al., 1998, 1999, 2000; Neidhart et al., 2000; Suzuki et al., 2000, 2003; Toft et al., 2000; Nieman et al., 2001, 2002, 2003, 2005, 2006, 2007; Starkie et al., 2001; Bonsignore et al., 2002; Pistilli et al., 2002; Uchakin et al., 2003; Mastaloudis et al., 2004; Miles et al., 2006; Kim et al., 2007; Siegel et al., 2007; Ng et al., 2008; Donnikov et al., 2009; Cox et al., 2010; Howatson et al., 2010; Scherr et al., 2011, 2012; Díaz-Castro et al., 2012; Nickel et al., 2012; Vaisberg et al., 2012, 2013; Abbasi et al., 2013; Bernecker et al., 2013; Chiu et al., 2013; Reihmane et al., 2013; Santos et al., 2013a, 2016; Shin and Lee, 2013; Wilhelm et al., 2014; Gill et al., 2015a,b; Luna Junior et al., 2016; Niemelä et al., 2016; Zimmer et al., 2016; Clifford et al., 2017; Passos et al., 2019; Pugh et al., 2019; Sierra et al., 2019a,b; Yargic et al., 2019; Batatinha et al., 2020; Costello et al., 2020; dos Santos et al., 2020; Kasprowicz et al., 2020; Larsen et al., 2020; Wołyniec et al., 2020; Benedetti et al., 2021; Gaggini et al., 2021; Skinner et al., 2021; Sliwicka et al., 2021). Of this total, only the studies of Reihmane et al. (2013) and Costello et al. (2020) (3\%) did not show increased concentration of IL-6 after half-marathon running.

\section{Interleukin $1 \beta$}

Nineteen studies were found that evaluated the IL-1 $\beta$ (Drenth et al., 1995; Ostrowski et al., 1998, 1999; Neidhart et al., 2000; Suzuki et al., 2000, 2003; Nieman et al., 2001; Uchakin et al., 2003; Ng et al., 2008; Gill et al., 2015a,b; Luna Junior et al., 2016; Santos et al., 2016; Clifford et al., 2017; Passos et al., 2019; Sierra et al., 2019a; Batatinha et al., 2020; dos Santos et al., 2020; Skinner et al., 2021). In these studies, 20 runs were evaluated [half-marathon $(n=1)$, ultra-marathon $(n=4)$, marathon $(n$ 


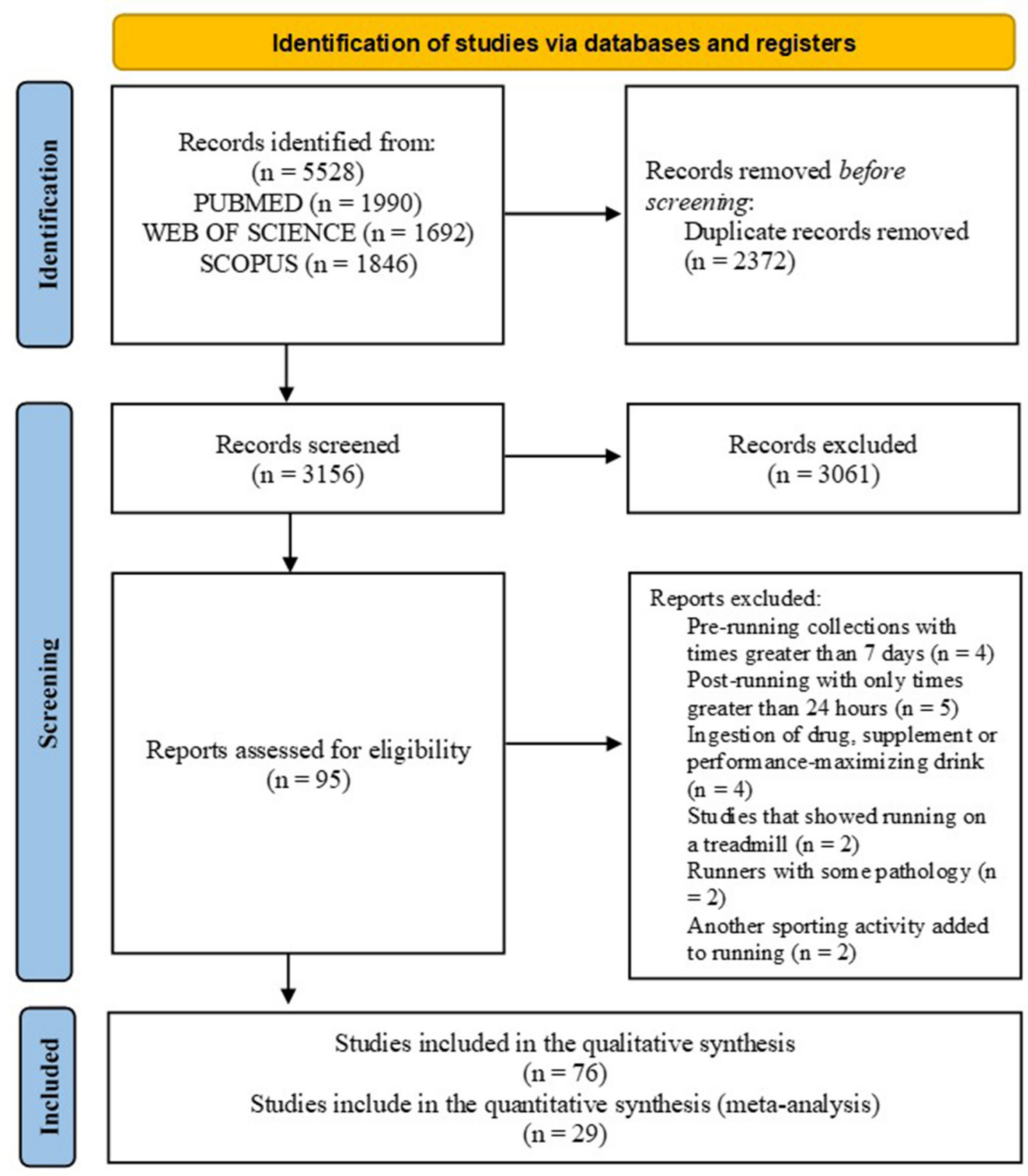

FIGURE 1 | The search flowchart for screening process.

$=14)$ and $40 \mathrm{~km}$ running $(n=1)]$, of this total, $(100 \%)$ halfmarathon (Ng et al., 2008) and $40 \mathrm{~km}$ (Skinner et al., 2021), (50\%) marathon (Neidhart et al., 2000; Suzuki et al., 2000; Uchakin et al., 2003; Luna Junior et al., 2016; Santos et al., 2016; Batatinha et al., 2020; dos Santos et al., 2020) e (25\%) ultra-marathon (Drenth et al., 1995), did not show increased concentration of IL$1 \beta$. When the behavior of IL-1 $\beta$ between two tests was analyzed $(40 \mathrm{~km}$ vs $171 \mathrm{~km})$ in the same study, IL- $1 \beta$ was increased only in the ultra-marathon running (Skinner et al., 2021).

\section{Interleukin-1 Receptor Antagonist}

Twenty-three studies were found that evaluated interleukin1 receptor antagonist (IL-1ra), in all run volumes evaluated (Drenth et al., 1995; Castell et al., 1996; Ostrowski et al., 1998, 1999, 2000; Neidhart et al., 2000; Suzuki et al., 2000; Toft et al., 2000; Nieman et al., 2001, 2002, 2003, 2005, 2006, 2007; Peters et al., 2001; Pistilli et al., 2002; Ng et al., 2008; Cox et al., 2010; Díaz-Castro et al., 2012; Abbasi et al., 2013; Santos et al., 2013a; Gill et al., 2015b; Clifford et al., 2017). Of this total, only the 


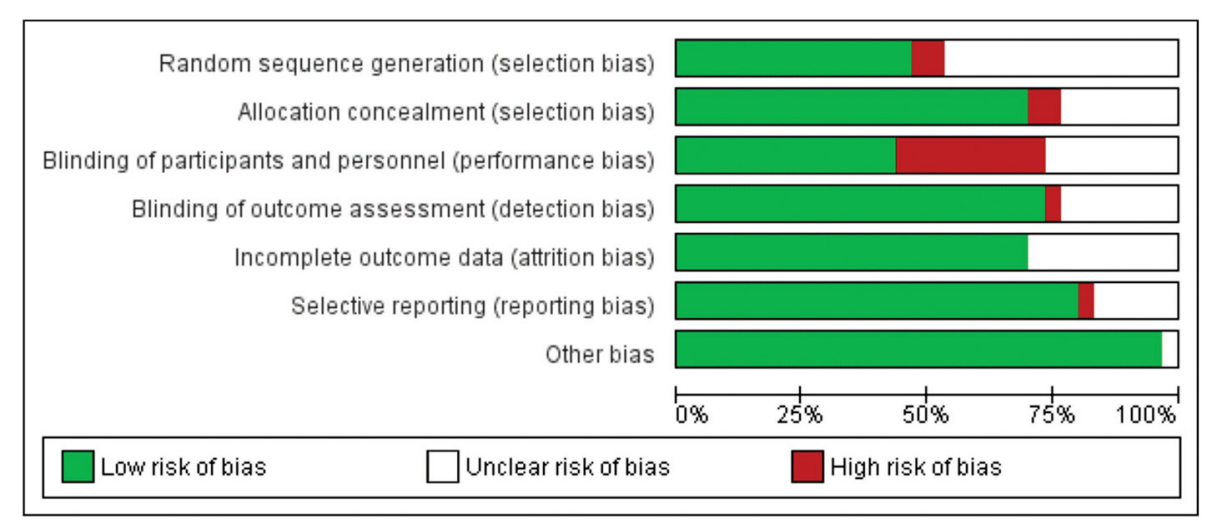

FIGURE 2 | Risk of bias evaluation of included studies.

study of Clifford et al. (2017) (3\%) showed no elevation in the concentration of IL-1ra after marathon running.

\section{Interleukin 2}

Eight studies were found that evaluated IL-2, in two runs studied, being six marathons (Castell et al., 1996; Suzuki et al., 2000; Santos et al., 2013b; Clifford et al., 2017; Batatinha et al., 2020; Tavares-Silva et al., 2021) and two ultra-marathon (Nieman et al., 2002; Skinner et al., 2021). Of this total, the studies of Castell et al. (1996), Suzuki et al. (2000) and Clifford et al. (2017) showed no decrease in IL-2 concentration and the studies by Nieman et al. (2002) and Skinner et al. (2021) demonstrated an increase in IL-2 concentration.

\section{Interleukin 4}

Seven studies were found that evaluated IL-4 (Suzuki et al., 2000; Luna Junior et al., 2016; Clifford et al., 2017; Batatinha et al., 2020; dos Santos et al., 2020; Skinner et al., 2021; Tavares-Silva et al., 2021). Of this total, only the study of Skinner et al. (2021) found an increase in IL-4 after a $171 \mathrm{~km}$ run.

\section{Interleukin 8}

Twenty-seven studies were found that evaluated IL- 8 , in the distances between half-marathon and ultra-marathon running ( $\leq 208 \mathrm{~km}$ ) (Niess et al., 1999; Fehrenbach et al., 2000; Suzuki et al., 2000, 2003; Nieman et al., 2001, 2002, 2003, 2005, 2006, 2007; Pistilli et al., 2002; Cox et al., 2010; Abbasi et al., 2013; Shanely et al., 2014; Bachi et al., 2015; Gill et al., 2015a; Luna Junior et al., 2016; Niemelä et al., 2016; Santos et al., 2016; Clifford et al., 2017; Passos et al., 2019; Pugh et al., 2019; Sierra et al., 2019a,b; Batatinha et al., 2020; dos Santos et al., 2020; Skinner et al., 2021). Of this total, only the studies of Bachi et al. (2015), Luna Junior et al. (2016) and Sierra et al. (2019a) (11\%) showed no increase in IL-8 concentration after marathon running.

\section{Interleukin $\mathbf{1 0}$}

Thirty-three studies were found that evaluated IL-10, about halfmarathon distances ( $\mathrm{Ng}$ et al., 2008; Cox et al., 2010; Abbasi et al., 2013; Niemelä et al., 2016), marathon (Suzuki et al.,
2000, 2003; Nieman et al., 2001; Pistilli et al., 2002; Scherr et al., 2011; Nickel et al., 2012; Santos et al., 2013b, 2016; Vaisberg et al., 2013; Shanely et al., 2014; Bachi et al., 2015; Luna Junior et al., 2016; Niemelä et al., 2016; Clifford et al., 2017; Passos et al., 2019; Pugh et al., 2019; Sierra et al., 2019b; Batatinha et al., 2020; dos Santos et al., 2020; Larsen et al., 2020; Tavares-Silva et al., 2021) and ultra-marathon (Peters et al., 2001; Nieman et al., 2002, 2003, 2005, 2006, 2007; Shin and Lee, 2013; Gill et al., 2015a,b). Of this total, one study did not showed an increase in the concentration of IL-10 after marathon running (Luna Junior et al., 2016). Furthermore, the study by Santos et al. (2013b) showed a reduction after marathon running.

\section{Tumor Necrosis Factor- $\alpha$}

Forty-three studies were found that evaluated TNF- $\alpha$. One study show a reduction in TNF- $\alpha$ concentration, after marathon running (Santos et al., 2013b). Nineteen investigations, showed no differences in TNF- $\alpha$ immediately after half-marathon, marathon and ultra-marathon running (Drenth et al., 1995; Castell et al., 1996; Fehrenbach et al., 2000; Bonsignore et al., 2002; Suzuki et al., 2003; Nieman et al., 2006; Kim et al., 2007; Ng et al., 2008; Nickel et al., 2012; Abbasi et al., 2013; Reihmane et al., 2013; Santos et al., 2013a, 2016; Luna Junior et al., 2016; Passos et al., 2019; Sierra et al., 2019b; Batatinha et al., 2020; Costello et al., 2020; Gaggini et al., 2021). Regarding the studies that showed an increase in TNF- $\alpha$ levels, such results were observed after half-marathon (Bonsignore et al., 2002; Zimmer et al., 2016), marathon (Ostrowski et al., 1998, 1999; Neidhart et al., 2000; Toft et al., 2000; Nieman et al., 2001; Starkie et al., 2001; Uchakin et al., 2003; Scherr et al., 2011; Vaisberg et al., 2012; Bernecker et al., 2013; Wilhelm et al., 2014; Clifford et al., 2017; dos Santos et al., 2020; Larsen et al., 2020; Sliwicka et al., 2021; Tavares-Silva et al., 2021), ultra-marathon with variability of distances between 50 and $230 \mathrm{~km}$ (Nieman et al., 2007; Díaz-Castro et al., 2012; Chiu et al., 2013; Gill et al., 2015a,b; Skinner et al., 2021) and in $40 \mathrm{~km}$ run (Skinner et al., 2021). 


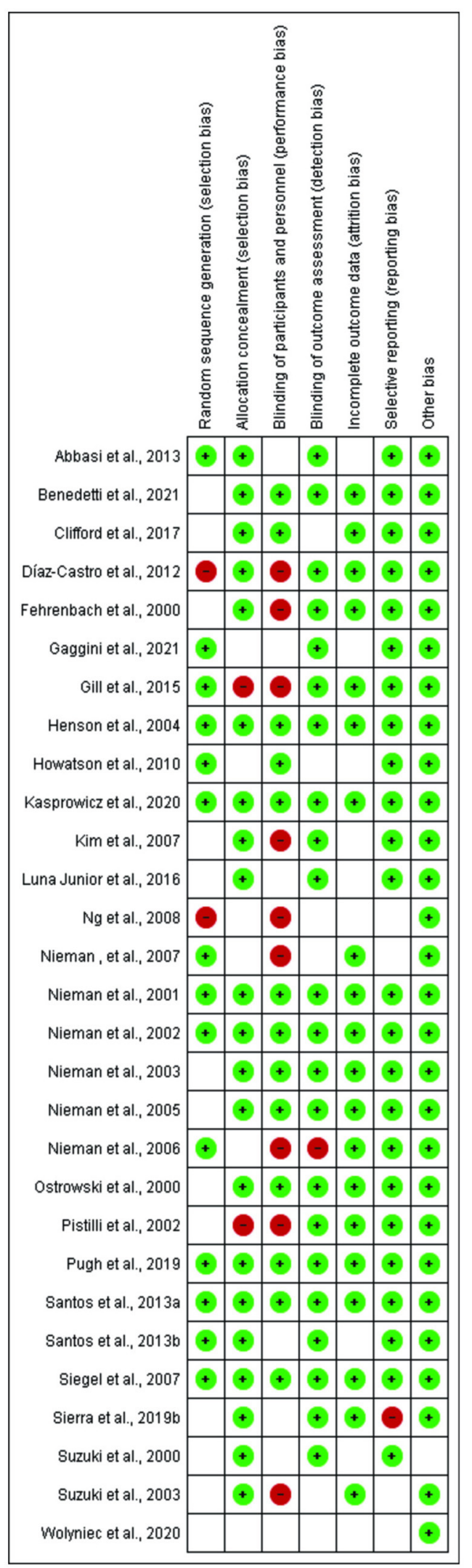

FIGURE 3 | Risk of bias summary.

\section{Interferon Gamma}

The Interferon gamma (IFN-y) was evaluated in nine studies (Suzuki et al., 2000; Nieman et al., 2002; Henson et al., 2004; Abbasi et al., 2013; Gill et al., 2015a,b; Clifford et al., 2017; Batatinha et al., 2020; Skinner et al., 2021). There was no change in IFN- $\gamma$ concentration in six studies (Suzuki et al., 2000; Abbasi et al., 2013; Gill et al., 2015b; Clifford et al., 2017; Batatinha et al., 2020; Skinner et al., 2021). In two studies, a decrease in IFN$\gamma$ concentration was found after running (Nieman et al., 2002; Henson et al., 2004), $80 \mathrm{~km}$ and marathon, respectively.

\section{Leptin, Resistin, Adiponectin, and Visfatin}

Five studies were found that evaluated the Leptin (Zaccaria et al., 2002; Bernecker et al., 2013; Roupas et al., 2013; Vuolteenaho et al., 2014; Sansoni et al., 2017). In the half-marathon and marathon running there were no significant changes (Zaccaria et al., 2002; Bernecker et al., 2013; Vuolteenaho et al., 2014). In the ultra-marathon running, Leptin levels reduced after the running (Zaccaria et al., 2002; Roupas et al., 2013; Sansoni et al., 2017). The Resistin was evaluated in four studies showing increased concentration after running (Roupas et al., 2013; Vuolteenaho et al., 2014; Sansoni et al., 2017; Czajkowska et al., 2020). Two studies were found that evaluated the concentration of adiponectin (Roupas et al., 2013; Vuolteenaho et al., 2014). There was an increase in adiponectin concentration after the marathon (Vuolteenaho et al., 2014). The Visfatin was evaluated in two studies (Roupas et al., 2013; Sansoni et al., 2017). Visfatin concentration increased only in the study that presented the lowest running volume $65 \mathrm{~km}$ (Sansoni et al., 2017).

\section{IL-12, IL-12p40, IL-12p70, IL-23, IL-33, IL-15, IL-7, IL-17a, IL-3, and IL-5}

The IL-12 was evaluated in two studies: (Santos et al., 2016; Skinner et al., 2021). There was no significant difference after the run, regardless of the distance covered. Two studies evaluated the IL-12p40: (Abbasi et al., 2013; Sierra et al., 2019a). The concentration of IL-12p40 was reduced after the marathon (Sierra et al., 2019a). The IL-12p70 was also evaluated in three studies (Abbasi et al., 2013; Passos et al., 2019; Sierra et al., 2019b). There was no change in IL-12p70, regardless of running volume. Only one study evaluated the IL-23 e IL33: (Sierra et al., 2019a), both cytokines reduced concentration after marathon (Sierra et al., 2019a). Only one study evaluated IL-15 and there was no change (Batatinha et al., 2020). IL-7 and IL-17a were evaluated in only one study (Skinner et al., 2021). Increases in the concentration of both cytokines were found after $170 \mathrm{~km}$ of running. Only one study evaluated IL-3 and IL-5 and there was no change (Skinner et al., 2021).

\section{VEGF-A, Fractalkine, sTNFRII, sIL-6R, TGF- $\beta$, G-CSF, GM-CSF, MCP-1, MIP-1 $\beta$, HSP72, HSP27, and HSP70}

Only one study evaluated VEGF-A, finding no differences after the half-marathon, on the other hand fractalkine, showed an 
TABLE 2 | The study characteristics of included studies.

\begin{tabular}{|c|c|c|c|c|c|c|c|}
\hline Authors & Objective & Distance & $\begin{array}{l}\text { No of } \\
\text { participant }\end{array}$ & Age & Sample & Measure points $\#$ & Findings \\
\hline Santos et al. (2013b) & $\begin{array}{l}\text { To investigate effects of DHA-Rich Fish Oil Supplementation } \\
\text { on Lymphocyte Function Before and After a Marathon race. }\end{array}$ & Marathon & 21 & $37 \pm 2$ & Blood & $\begin{array}{l}3 \text { to } 7 \text { days before and } \\
\text { immediately after the } \\
\text { running. }\end{array}$ & $\downarrow$ IL-2, IL-10 and TNF- $\alpha$ \\
\hline $\begin{array}{l}\text { Bernecker et al. } \\
\text { (2013) }\end{array}$ & $\begin{array}{l}\text { To investigate blood parameters of healthy men before and } \\
\text { immediately after a marathon race. }\end{array}$ & Marathon & 15 & 43 & Blood & $\begin{array}{l}\text { Directly before and } \\
\text { immediately after the } \\
\text { running. }\end{array}$ & $\uparrow$ IL-6 and TNF- $\alpha . \leftrightarrow$ Leptin \\
\hline Nieman et al. (2006) & $\begin{array}{l}\text { To measure the influence of ibuprofen use during the } 160-\mathrm{km} \\
\text { Western States Endurance Run on endotoxemia, } \\
\text { inflammation, and plasma cytokines. }\end{array}$ & $160 \mathrm{~km}$ & 30 & $46 \pm 2$ & Blood & $\begin{array}{l}\text { The morning before the } \\
\text { running and } 10 \text { to } \\
15 \text { min after the running. }\end{array}$ & $\begin{array}{l}\uparrow \mathrm{IL}-6, \mathrm{IL}-1 \mathrm{ra}, \mathrm{IL}-8, \mathrm{IL}-10, \mathrm{G}-\mathrm{CSF}, \mathrm{MCP}-1 \\
\text { and MIP-1 } \beta . \leftrightarrow \mathrm{TNF}-\alpha\end{array}$ \\
\hline Shin and Lee (2013) & $\begin{array}{l}\text { The aim of this study was to assess leukocyte chemotactic } \\
\text { cytokine and leukocyte subset responses during } \\
\text { ultra-marathon running. }\end{array}$ & $308 \mathrm{~km}$ & 60 & $52 \pm 5$ & Blood & $\begin{array}{l}\text { Before and immediately } \\
\text { after the running. }\end{array}$ & $\uparrow \mathrm{IL}-6$ and IL-10 \\
\hline Ng et al. (2008) & $\begin{array}{l}\text { This study investigated changes in plasma LPS concentration } \\
\text { and immune responses (leukocyte subsets and cytokines) } \\
\text { during a half-marathon race in warm and humid conditions. }\end{array}$ & $\begin{array}{l}\text { Half- } \\
\text { marathon }\end{array}$ & 32 & $25 \pm 3$ & Blood & $\begin{array}{l}\text { Before and immediately } \\
\text { after the running. }\end{array}$ & $\begin{array}{l}\uparrow \text { IL-6, IL-10 and IL-1ra; } \leftrightarrow \text { TNF- } \alpha \text { and } \\
\text { IL-1 } \beta\end{array}$ \\
\hline Nieman et al. (2007) & $\begin{array}{l}\text { The purpose of this study was to measure the influence of } \\
\text { quercetin on plasma cytokines, leukocyte cytokine mRNA, and } \\
\text { related variables in ultramarathoners competing in the 160-km } \\
\text { Western States Endurance Run. }\end{array}$ & $160 \mathrm{~km}$ & 63 & $44 \pm 2$ & Blood & $\begin{array}{l}\text { The morning before the } \\
\text { test and } 10 \text { to } 15 \mathrm{~min} \\
\text { after the running. }\end{array}$ & $\begin{array}{l}\uparrow I L-6, \text { IL-1ra, IL-8, IL-10, TNF- } \alpha, \text { G-CSF, } \\
\text { MCP-1 and MIP- } 1 \beta\end{array}$ \\
\hline Roupas et al. (2013) & $\begin{array}{l}\text { To evaluate the effect of prolonged intensive aerobic exercise } \\
\text { and acute energy deficit (ultra-marathon endurance race of } \\
180 \mathrm{~km} \text { distance) on serum leptin, adiponectin, resistin and } \\
\text { visfatin levels. }\end{array}$ & $180 \mathrm{~km}$ & 17 & $51 \pm 6$ & Blood & $\begin{array}{l}\text { Running morning, } \\
\text { post-running and } 17 \text { to } \\
22 \mathrm{~h} \text { after the running. }\end{array}$ & $\begin{array}{l}\uparrow \text { Resistin; } \leftrightarrow \text { Adiponectin and Visfatin; } \downarrow \\
\text { Leptin }\end{array}$ \\
\hline Niess et al. (1999) & $\begin{array}{l}\text { We supposed that the down-regulation of the baseline } \\
\text { concentration of } \mathrm{HO}-1 \text { in athletes reflects an adaptional } \\
\text { mechanism to regular exercise training. }\end{array}$ & $\begin{array}{l}\text { Half- } \\
\text { marathon }\end{array}$ & 10 & - & Blood & $\begin{array}{l}\text { Before, immediately, } 3 \mathrm{~h} \\
\text { and } 24 \mathrm{~h} \text { after the } \\
\text { running. }\end{array}$ & $\begin{array}{l}\uparrow I L-8 \text { immediately and then the values } \\
\text { returned to baseline. }\end{array}$ \\
\hline Sliwicka et al. (2021) & $\begin{array}{l}\text { The aim of this study was to evaluate the effects of a marathon } \\
\text { race on selected myokines and sclerostin in } 10 \text { male } \\
\text { recreational runners. }\end{array}$ & Marathon & 10 & $41 \pm 7$ & Blood & $\begin{array}{l}24 \mathrm{~h} \text { before, } 24 \text { and } 72 \mathrm{~h} \\
\text { after the running. }\end{array}$ & $\uparrow$ IL-6 and TNF- $\alpha$ \\
\hline $\begin{array}{l}\text { Ostrowski et al. } \\
\text { (2000) }\end{array}$ & $\begin{array}{l}\text { The present study included data from three marathon races to } \\
\text { investigate the hypothesis that a relationship exists between } \\
\text { running intensity and elevated concentrations of interleukin } \\
\text { (IL)-6 in plasma. }\end{array}$ & Marathon & 53 & 30 & Blood & $\begin{array}{l}\text { One week before, } \\
\text { immediately, } 1.5 \mathrm{~h} \text { and } \\
3 \mathrm{~h} \text { after the running. }\end{array}$ & $\begin{array}{l}\uparrow \mathrm{IL}-6 \text { and IL-1r } \alpha \text { at } 1.5 \mathrm{~h} \text { and then the } \\
\text { values returned to baseline. }\end{array}$ \\
\hline Zaccaria et al. (2002) & $\begin{array}{l}\text { With the aim of clarifying the relationship between the level of } \\
\mathrm{EE} \text { and the reduction in leptin levels. }\end{array}$ & $\begin{array}{l}\text { Half- } \\
\text { marathon } \\
(\mathrm{HM}) \text { and } \\
100 \mathrm{~km}\end{array}$ & $\begin{array}{l}\mathrm{HM}: 23 \text { and } \\
100 \mathrm{~km}: 11\end{array}$ & $\begin{array}{l}\mathrm{HM}: 44 \pm 2 \\
100 \mathrm{~km}: 46 \\
\pm 3\end{array}$ & Blood & $\begin{array}{l}\text { Immediately before and } \\
\text { immediately after the } \\
\text { running. }\end{array}$ & HM: $\leftrightarrow$ Leptin 100 km: $\downarrow$ Leptin \\
\hline $\begin{array}{l}\text { Czajkowska et al. } \\
\text { (2020) }\end{array}$ & $\begin{array}{l}\text { To evaluate the effect of continuous, prolonged, } \\
\text { moderate-intensity running exercise, such as running a } 100 \mathrm{~km} \\
\text { ultra-marathon, and acute energy deficit on serum levels of } \\
\text { pro-inflammatory adipokines: resistin and chemerin. }\end{array}$ & $100 \mathrm{~km}$ & 15 & $42 \pm 8$ & Blood & $\begin{array}{l}\text { Before and after the } \\
\text { running. }\end{array}$ & $\uparrow$ Resistin; $\leftrightarrow$ Chemerin \\
\hline
\end{tabular}




\begin{tabular}{|c|c|c|c|c|c|c|c|}
\hline Authors & Objective & Distance & $\begin{array}{l}\text { No of } \\
\text { participant }\end{array}$ & Age & Sample & Measure points $\#$ & Findings \\
\hline $\begin{array}{l}\text { Vuolteenaho et al. } \\
\text { (2014) }\end{array}$ & $\begin{array}{l}\text { The aim of the present study was to investigate the effects of } \\
\text { marathon running on the levels of adipokines adiponectin, } \\
\text { leptin and resistin, as well as on markers associated with } \\
\text { cartilage degradation in inflammatory arthritis and } \\
\text { osteoarthritis. }\end{array}$ & Marathon & 46 & $40 \pm 9$ & Blood & $\begin{array}{l}1 \text { day before and } \\
\text { immediately after the } \\
\text { running. }\end{array}$ & $\uparrow$ Resistina and Adiponectin; $\leftrightarrow$ Leptin \\
\hline Vaisberg et al. (2013) & $\begin{array}{l}\text { The aim of this study was to evaluate the immune response } \\
\text { elicited by exhaustive exercise in different compartments, } \\
\text { namely, the local (upper airway mucosa) and systemic (serum) } \\
\text { compartments, by comparing athletes that presented or not } \\
\text { with symptoms of upper airway disease after completing a } \\
\text { marathon. }\end{array}$ & Marathon & 22 & $41 \pm 9$ & $\begin{array}{l}\text { Blood (B) } \\
\text { and nasal (N) }\end{array}$ & $\begin{array}{l}\text { Before, immediately and } \\
72 \mathrm{~h} \text { after the running. }\end{array}$ & S: $\uparrow$ IL-6 and IL-10; N: $\uparrow$ IL-6; N: ↔ IL-10 \\
\hline Kim et al. (2007) & $\begin{array}{l}\text { The present study evaluated muscle and cartilage biomarkers, } \\
\text { and cytokine concentration during a } 200 \mathrm{~km} \text { running event. }\end{array}$ & $200 \mathrm{~km}$ & 54 & $45 \pm 5$ & Blood & $\begin{array}{l}10-12 \mathrm{~h} \text { before, } \\
\text { immediately after the } \\
100 \mathrm{~km} \text { and at the end } \\
\text { of the } 200 \mathrm{~km} \text {. }\end{array}$ & $\uparrow I L-6 ; \leftrightarrow$ TNF- $\alpha$ \\
\hline Starkie et al. (2001) & $\begin{array}{l}\text { To investigate whether prolonged, strenuous running affects } \\
\text { the ability of circulating monocytes to produce cytokines upon } \\
\text { stimulation and whether spontaneous cytokine production is } \\
\text { responsible, in part, for the increased plasma cytokine } \\
\text { concentration. }\end{array}$ & Marathon & 5 & - & Blood & $\begin{array}{l}1 \mathrm{~h} \text { before the running, } \\
\text { immediately, } 2 \mathrm{~h} \text { and } \\
24 \mathrm{~h} \text { after the running. }\end{array}$ & $\begin{array}{l}\uparrow I L-6 \text { at all periods after the running and } \\
\text { TNF- } \alpha \text { only at } 2 \mathrm{~h} \text { and then the values } \\
\text { returned to baseline. }\end{array}$ \\
\hline Gaggini et al. (2021) & $\begin{array}{l}\text { Evaluate the changes in plasma levels of these bioactive lipids } \\
\text { in healthy runners performing a half-marathon, at the end of } \\
\text { the race and after } 24 \mathrm{~h} \text { recovery, and their associations with } \\
\text { new recently proposed and common biomarkers of immune } \\
\text { activation. }\end{array}$ & $\begin{array}{l}\text { Half- } \\
\text { marathon }\end{array}$ & 13 & $47 \pm 6$ & Blood & $\begin{array}{l}1 \text { day before, } \\
\text { immediately and } 24 \mathrm{~h} \\
\text { after the running. }\end{array}$ & $\begin{array}{l}\uparrow I L-6 \text { and fractalkine only immediately } \\
\text { and then the values returned to baseline. } \\
\leftrightarrow \text { TNF- } \alpha \text { and VEGF-A }\end{array}$ \\
\hline Castell et al. (1996) & $\begin{array}{l}\text { The present study investigated white blood cell numbers, } \\
\text { together with the plasma concentrations of some amino acids, } \\
\text { cytokines and some acute phase response markers in athletes } \\
\text { after two separate marathon races }\end{array}$ & Marathon & 38 & $20-40$ & Blood & $\begin{array}{l}30 \mathrm{~min} \text { before, } 15 \mathrm{~min} \text {, } \\
1 \mathrm{~h} \text { and } 16 \mathrm{~h} \text { after the } \\
\text { running. }\end{array}$ & $\begin{array}{l}\uparrow \mathrm{IL}-6 \text { only immediately and } 1 \mathrm{~h} \text { and IL-2 } \\
\text { only } 16 \mathrm{~h} \text { after the running. } \leftrightarrow \mathrm{IL}-2 \text { only } \\
\text { immediately and } 1 \mathrm{~h} \text { and IL-1 } \alpha \text { and TNF- } \alpha \\
\text { at all periods after the running. }\end{array}$ \\
\hline Drenth et al. (1995) & $\begin{array}{l}\text { Investigated whether a } 6 \mathrm{~h} \text { endurance race such as binding } \\
\text { plasma cytokine changes and lipopolysaccharides (LPS) } \\
\text { stimulated ex vivo cytokine production in a whole blood culture } \\
\text { of } 19 \text { well-trained athletes. }\end{array}$ & $51-86 \mathrm{~km}$ & 71 & $43 \pm 8$ & Blood & $\begin{array}{l}\sim 18 \mathrm{~h} \text { before and } \\
\text { immediately after the } \\
\text { running. }\end{array}$ & $\uparrow \mathrm{IL}-6$ and IL-1ra; $\leftrightarrow \mathrm{IL}-1 \beta$ and TNF- $\alpha$ \\
\hline $\begin{array}{l}\text { dos Santos et al. } \\
(2020)\end{array}$ & $\begin{array}{l}\text { To evaluate the prevalence of EIB in a group of recreational } \\
\text { marathon runners without asthma, as well as to investigate } \\
\text { both systemic and upper airway inflammatory responses and } \\
\text { their correlation with marathon performance. }\end{array}$ & Marathon & 38 & 38 [33-44] & Blood & $\begin{array}{l}24 \mathrm{~h} \text { before and } \\
\text { immediately after the } \\
\text { running. }\end{array}$ & $\begin{array}{l}\uparrow \text { IL-6, IL-8, IL-10 and TNF- } \alpha ; \leftrightarrow \text { IL-1 } \beta \\
\text { and IL-4 }\end{array}$ \\
\hline Uchakin et al. (2003) & $\begin{array}{l}\text { To investigate the effects of marathon-associated stressors on } \\
\text { cell-mediated versus humoral and anti-inflammatory versus } \\
\text { pro-inflammatory balance, as well as their correlations with } \\
\text { neuroendocrine response. }\end{array}$ & Marathon & 15 & 39 & Blood & $\begin{array}{l}24 \mathrm{~h} \text { before, } \\
\text { immediately, } 1 \mathrm{~h}, 24 \mathrm{~h}, \\
48 \mathrm{~h}, 5 \text { days and } 8 \text { days } \\
\text { after the running. }\end{array}$ & $\begin{array}{l}\uparrow \mathrm{IL}-6 \text { only immediately and } 1 \mathrm{~h} \text { and TNF- } \alpha \\
\text { only immediately; } \leftrightarrow \mathrm{LL}-1 \beta\end{array}$ \\
\hline
\end{tabular}




\begin{tabular}{|c|c|c|c|c|c|c|c|}
\hline Authors & Objective & Distance & $\begin{array}{l}\text { No of } \\
\text { participant }\end{array}$ & Age & Sample & Measure points" & Findings \\
\hline Suzuki et al. (2003) & $\begin{array}{l}\text { To investigate whether cytokines and neutrophils mediate } \\
\text { exercise-related pathogenesis, we examined their responses } \\
\text { and possible association after exhaustive exercise. }\end{array}$ & Marathon & 10 & $31 \pm 5$ & $\begin{array}{l}\text { Blood }(B) \\
\text { and urine }(U)\end{array}$ & $\begin{array}{l}1 \text { day before and } 10 \mathrm{~min} \\
\text { after the running. }\end{array}$ & 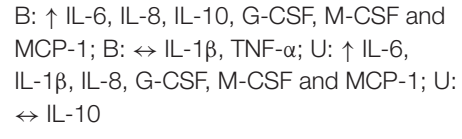 \\
\hline $\begin{array}{l}\text { Bonsignore et al. } \\
\text { (2002) }\end{array}$ & $\begin{array}{l}\text { Analyze whether the amount or duration of endurance exercise } \\
\text { could modulate inflammatory and stress mediators, as well as } \\
\text { circulating HPC counts. }\end{array}$ & $\begin{array}{l}\text { Half- } \\
\text { marathon } \\
(\mathrm{HM}) \text { and } \\
\text { Marathon } \\
\text { (Ma) }\end{array}$ & 18 & $41 \pm 13$ & Blood & $\begin{array}{l}9 \pm 2 \text { days before, } \\
\text { immediately and } \sim 24 \mathrm{~h} \\
\text { after. }\end{array}$ & $\begin{array}{l}\mathrm{HM}: \uparrow I \mathrm{~L}-6, \mathrm{TNF}-\alpha \text { and G-CSF only } \\
\text { immediately and then the values returned } \\
\text { to baseline. Ma: } \uparrow \mathrm{IL}-6 \text { and G-CSF and } \\
\text { then the values returned to baseline. Ma: } \\
\leftrightarrow \mathrm{TNF}-\alpha\end{array}$ \\
\hline Neidhart et al. (2000) & $\begin{array}{l}\text { Compare cytokine response with cartilage oligomeric matrix } \\
\text { levels protein (COMP) and melanoma inhibitory activity (MIA) } \\
\text { after marathon. }\end{array}$ & Marathon & 8 & - & Blood & $\begin{array}{l}\text { Before the running, after } \\
31 \mathrm{~km} \text {, after the running, } \\
1 \text { hour, } 1 \text { day and } 2 \\
\text { days after the running. }\end{array}$ & $\begin{array}{l}\uparrow I \mathrm{IL}-6 \text { only immediately; IL-1ra and TNF- } \alpha \\
\text { only immediately and } 1 \mathrm{~h} \text {, then the values } \\
\text { returned to baseline. } \leftrightarrow \mathrm{IL}-1 \beta \text {, sTNFRII } \\
\text { and sIL-6R }\end{array}$ \\
\hline $\begin{array}{l}\text { Fehrenbach et al. } \\
\text { (2000) }\end{array}$ & $\begin{array}{l}\text { To verify whether the regulation of basal HSP expression in } \\
\text { immunocompetent cells exhibits adaptation due to regular } \\
\text { endurance training. }\end{array}$ & $\begin{array}{l}\text { Half- } \\
\text { marathon }\end{array}$ & 12 & $32 \pm 9$ & Blood & $\begin{array}{l}24 \mathrm{~h} \text { before, } \\
\text { immediately, } 3 \mathrm{~h} \text { and } \\
24 \mathrm{~h} \text { after. }\end{array}$ & $\begin{array}{l}\uparrow I \mathrm{~L}-8 \text { only immediately and then the } \\
\text { values returned to baseline. } \leftrightarrow \text { TNF- } \alpha\end{array}$ \\
\hline Suzuki et al. (2000) & $\begin{array}{l}\text { Investigate the mechanisms of exercise-induced immune } \\
\text { perturbations. }\end{array}$ & Marathon & 16 & $21-39$ & Blood & $\begin{array}{l}24 \mathrm{~h} \text { before and after the } \\
\text { running. }\end{array}$ & $\begin{array}{l}\uparrow \text { IL-6, IL-1ra, IL-8, IL-10 and G-CSF; } \leftrightarrow \\
\text { IL-1 } 1 \beta, \text { IL-2, IL-4 and IFN- } \gamma\end{array}$ \\
\hline Sierra et al. (2019a) & $\begin{array}{l}\text { Aimed at investigating whether marathon causes cardiac } \\
\text { fatigue and, if it is the case, whether cardiac fatigue correlates } \\
\text { with pulmonary levels of eNO and pulmonary inflammation. }\end{array}$ & Marathon & 31 & $39 \pm 9$ & Sputum & $\begin{array}{l}24 \mathrm{~h} \text { before and } \\
\text { immediately after the } \\
\text { running. }\end{array}$ & $\leftrightarrow \mathrm{IL}-6, \mathrm{IL}-8 ; \downarrow$ IL-12p40, IL-23 and IL-33 \\
\hline Clifford et al. (2017) & $\begin{array}{l}\text { Examine whether beetroot juice (BTJ) would alleviate } \\
\text { inflammation and muscle damage after a marathon. }\end{array}$ & Marathon & 34 & $39 \pm 12$ & Blood & $\begin{array}{l}\text { Before, after, } 24 \text { and } \\
48 \mathrm{~h} \text { after the running. }\end{array}$ & $\begin{array}{l}\uparrow \text { IL- } 6 \text { only immediately and } 24 \mathrm{~h}, \mathrm{IL}-1 \beta \text {, } \\
\text { IL- } 8 \text { e IL-10, IFN-y and TNF- } \alpha \text { only } \\
\text { immediately, then the values returned to } \\
\text { baseline. } \leftrightarrow \text { IL-1ra, IL-2, MCP-1 and IL- } 4\end{array}$ \\
\hline Santos et al. (2016) & $\begin{array}{l}\text { To determine whether running a marathon race affects } \\
\text { neutrophil function and to characterize the underlying } \\
\text { mechanisms. }\end{array}$ & Marathon & 23 & $34 \pm 6$ & Blood & $\begin{array}{l}24 \mathrm{~h} \text { before, } \\
\text { immediately, } 24 \mathrm{~h} \text { and } \\
72 \mathrm{~h} \text { after the running. }\end{array}$ & $\begin{array}{l}\uparrow \| \mathrm{IL}-6 \text { and IL- } 8 \text { only immediately and } 24 \mathrm{~h} \text {; } \\
\mathrm{IL}-10 \text { only immediately and then the values } \\
\text { returned to baseline. } \leftrightarrow \mathrm{IL}-1 \beta, \mathrm{IL}-12 \text { and } \\
\text { TNF- } \alpha\end{array}$ \\
\hline Niemelä et al. (2016) & $\begin{array}{l}\text { In order to shed more light on immune system function in } \\
\text { response to acute exercise episodes, we compared pre- and } \\
\text { post-race values of conventional and new biomarkers of } \\
\text { immune activation, including suPAR, CD163, pro-inflammatory } \\
\text { (IL-6, IL-8, tumor necrosis factor- } \alpha \text { [TNF- } \alpha] \text {, anti-inflammatory } \\
\text { (IL-10, growth factor- } \beta \text { [TGF- } \beta] \text { ), cytokines and muscle, } \\
\text { cardiac, renal and hepatic status markers, among typical } \\
\text { casual long-distance running event participants. }\end{array}$ & $\begin{array}{l}\text { Half- } \\
\text { marathon } \\
(\mathrm{HM}) \text { and } \\
\text { Marathon } \\
(\mathrm{Ma})\end{array}$ & HM: 4; Ma: 4 & $\begin{array}{l}\text { HM: } 39 \pm \\
\text { 13; Ma: } 26 \\
\pm 15\end{array}$ & Blood & $\begin{array}{l}24 \mathrm{~h} \text { before, } 3 \mathrm{~h} \text { and } \\
48 \mathrm{~h} \text { after the running. }\end{array}$ & $\begin{array}{l}\mathrm{HM} \text { and Ma: } \uparrow \mathrm{IL}-6, \mathrm{IL}-8 \text { and IL-10 only } \\
3 \mathrm{~h} \text { and then the values returned to } \\
\text { baseline. } \leftrightarrow \text { TNF- } \alpha \text { and TGF- } \beta\end{array}$ \\
\hline $\begin{array}{l}\text { Luna Junior et al. } \\
\text { (2016) }\end{array}$ & $\begin{array}{l}\text { Was to evaluate if there is some relation between } \mathrm{RE} \text { and } \\
\text { cytokine production in amateur marathon runners. }\end{array}$ & Marathon & 22 & $34 \pm 6$ & Blood & $\begin{array}{l}24 \mathrm{~h} \text { before, immediately } \\
\text { and } 72 \mathrm{~h} \text { after. }\end{array}$ & $\begin{array}{l}\leftrightarrow \mathrm{IL}-6, \mathrm{IL}-1 \beta, \mathrm{IL}-4, \mathrm{IL}-8, \mathrm{IL}-10 \text { and } \mathrm{TNF}-\alpha \\
\text { at all periods after the running. }\end{array}$ \\
\hline Shanely et al. (2014) & $\begin{array}{l}\text { To measure the influence of RR supplementation on } \\
\text { exercise-induced muscle damage, delayed onset of muscle } \\
\text { pain (DMIT), plasma cytokines, and extracellular HSP72 } \\
\text { (eHSP72) in experienced runners completing a marathon. }\end{array}$ & Marathon & 48 & $43 \pm 1$ & Blood & $\begin{array}{l}24 \mathrm{~h} \text { before, immediately } \\
\text { and } 1,5 \mathrm{~h} \text { after the } \\
\text { Marathon. }\end{array}$ & $\begin{array}{l}\uparrow I \mathrm{IL}-8, \mathrm{MCP}-1, \mathrm{IL}-10, \mathrm{IL}-6, \mathrm{G}-\mathrm{CSF} \text { and } \\
\text { eHSP72 at all periods after the running. }\end{array}$ \\
\hline
\end{tabular}




\begin{tabular}{|c|c|c|c|c|c|c|c|}
\hline Authors & Objective & Distance & $\begin{array}{l}\text { No of } \\
\text { participant }\end{array}$ & Age & Sample & Measure points ${ }^{\#}$ & Findings \\
\hline Abbasi et al. (2013) & $\begin{array}{l}\text { Was studied the ability of blood cultures to produce cytokines } \\
\text { in response to endotoxin (LPS) in athletes before, } 30 \text { min after, } \\
3 \mathrm{~h} \text { after and } 24 \mathrm{~h} \text { after a half-marathon. }\end{array}$ & $\begin{array}{l}\text { Half- } \\
\text { marathon }\end{array}$ & $16(8 \mathrm{M} ; 8 \mathrm{~F})$ & $\begin{array}{l}34 \pm 9 / 38 \\
\pm 5\end{array}$ & Blood & $\begin{array}{l}\text { Before, } 30 \mathrm{~min}, 3 \text { and } \\
24 \mathrm{~h} \text { after the running. }\end{array}$ & $\begin{array}{l}\text { M: } \uparrow \text { IL- } 6, \text { MCP- } 1 \text { and TGF- } \beta \text { only } 30 \text { min, } \\
\mathrm{IL}-1 \text { ra and IL- } 8 \text { only } 30 \text { min and } 3 \mathrm{~h} \text { and } \\
\mathrm{LL}-10 \text { at all periods after the running. } \leftrightarrow \\
\mathrm{IL}-12 \mathrm{p} 40, \mathrm{LL}-12 \mathrm{p} 70, \text { TNF- } \alpha \text { and IFN-y at } \\
\text { all periods after the running. F: } \uparrow \mathrm{IL}-6, \mathrm{IL}-8 \\
\text { and MCP- }-1 \text { only } 30 \text { min, IL-1ra only } 3 \mathrm{~h} \text {, } \\
\mathrm{IL}-10 \text { only } 30 \mathrm{~min} \text { and } 3 \mathrm{~h} \text {. F: } \leftrightarrow \mathrm{IL}-12 \mathrm{p} 40 \text {, } \\
\mathrm{IL}-12 \mathrm{p} 70, \text { TNF- } \alpha \text {, IFN-y and TGF- } \beta \text { at all } \\
\text { periods after the running. }\end{array}$ \\
\hline $\begin{array}{l}\text { Howatson et al. } \\
\text { (2010) }\end{array}$ & $\begin{array}{l}\text { The purpose of this study was to examine the effect of a tart } \\
\text { cherry juice blend taken before and following running a } \\
\text { Marathon on markers of muscle damage, inflammation, and } \\
\text { oxidative stress. }\end{array}$ & Marathon & 20 & $38 \pm 5$ & Blood & $\begin{array}{l}24 \mathrm{~h} \text { before, } \\
\text { immediately, } 24 \text { and } \\
48 \mathrm{~h} \text { after the running. }\end{array}$ & $\begin{array}{l}\uparrow \mathrm{IL}-6 \text { only immediately and then the } \\
\text { values returned to baseline. }\end{array}$ \\
\hline Vaisberg et al. (2012) & $\begin{array}{l}\text { Investigated the effects of acute exhaustive exercise on lipid } \\
\text { transfer to HDL. }\end{array}$ & Marathon & 14 & $38 \pm 7$ & Urine & $\begin{array}{l}\text { Before, immediately and } \\
72 \mathrm{~h} \text { after the running. }\end{array}$ & $\begin{array}{l}\uparrow I L-6 \text { and TNF- } \alpha \text { only immediately and } \\
\text { then the values returned to baseline. }\end{array}$ \\
\hline Costello et al. (2020) & $\begin{array}{l}\text { Was to examine the effect of NZBC extract supplementation } \\
\text { taken before and following running a half-marathon race on } \\
\text { markers of EIMD. }\end{array}$ & $\begin{array}{l}\text { Half- } \\
\text { marathon }\end{array}$ & 20 & $29 \pm 7$ & Blood & $\begin{array}{l}\text { Before, immediately, } 24 \\
\text { and } 48 \mathrm{~h} \text { after the } \\
\text { running. }\end{array}$ & $\leftrightarrow \mathbb{L}-6$ at all periods after the running. \\
\hline Cox et al. (2010) & $\begin{array}{l}\text { To investigate the effectiveness of Difflam in alleviating } \\
\text { post-race inflammatory responses and URS in trained runners } \\
\text { competing in a half marathon. }\end{array}$ & $\begin{array}{l}\text { Half- } \\
\text { marathon }\end{array}$ & 20 & $35 \pm 8$ & Blood & $\begin{array}{l}24 \mathrm{~h} \text { before and } \\
\text { immediately after the } \\
\text { running. }\end{array}$ & 个 IL-6, IL-1ra, IL-8 and IL-10 \\
\hline Peters et al. (2001) & $\begin{array}{l}\text { To evaluate the effects of vitamin C supplementation on } \\
\text { changes in circulating concentrations of cortisol, adrenaline, } \\
\text { interleukin-10 (IL-10) and interleukin-1 receptor antagonist } \\
\text { (IL-1Ra) that accompany the running in the ultramarathon were } \\
\text { measured by immuno- chemiluminescence, } \\
\text { radioimmunoassay and ELISA procedures. }\end{array}$ & $90 \mathrm{~km}$ & 29 & $39 \pm 7$ & Blood & $\begin{array}{l}24 \mathrm{~h} \text { before, } \\
\text { immediately, } 24 \text { and } \\
48 \mathrm{~h} \text { after the running. }\end{array}$ & $\begin{array}{l}\uparrow I L-1 \text { ra and IL- } 10 \text { only immediately and } \\
\text { then the values returned to baseline. }\end{array}$ \\
\hline Sierra et al. (2019b) & $\begin{array}{l}\text { Was to determine the extent of association between the AGT } \\
\text { Met } 235 T h r, A C E ~ I / D \text { and BDKRB } 2+9 /-9 \text { polymorphisms with } \\
\text { inflammation, myocardial and muscle injury, induced by } \\
\text { endurance exercise. }\end{array}$ & Marathon & 81 & $39 \pm 1$ & Blood & $\begin{array}{l}24 \mathrm{~h} \text { before, } \\
\text { immediately, } 24,72 \mathrm{~h} \\
\text { and } 15 \text { days after the } \\
\text { running. }\end{array}$ & $\begin{array}{l}\uparrow \mathrm{IL}-6, \mathrm{IL}-1 \beta, \mathrm{IL}-8 \text { and IL-10 only } \\
\text { immediately and then the values returned } \\
\text { to baseline. } \leftrightarrow \text { TNF- } \alpha \text { and IL-12p70 at all } \\
\text { periods after the running. }\end{array}$ \\
\hline $\begin{array}{l}\text { Wołyniec et al. } \\
\text { (2020) }\end{array}$ & $\begin{array}{l}\text { Investigate post-exercise proteinuria (PEP) after long exercise - } \\
\text { marathon and ultramarathon races. }\end{array}$ & $100 \mathrm{~km}$ & 17 & $40 \pm 4$ & Blood & $\begin{array}{l}\text { Immediately before and } \\
\text { after the running. }\end{array}$ & $\uparrow I L-6$ \\
\hline Pugh et al. (2019) & $\begin{array}{l}\text { To evaluate the effects of probiotic supplementation on } \\
\text { gastrointestinal (Gl) symptoms, circulatory markers of Gl } \\
\text { permeability, damage and immune response markers during a } \\
\text { marathon. }\end{array}$ & Marathon & 24 & $36 \pm 7$ & Blood & $\begin{array}{l}\text { Before and immediately } \\
\text { after the running. }\end{array}$ & $\uparrow$ IL-6, IL-8 and IL-10 \\
\hline Scherr et al. (2011) & $\begin{array}{l}\text { We investigated the kinetics of specific cardiac biomarkers } \\
\text { (h-FABP, hs-cTnT, NT-proBNP), inflammatory markers } \\
\text { (interleukin-10 (IL-10), IL-6, high-sensitive C-reactive protein } \\
\text { (hs-CRP), and TNF- } \alpha \text { ), and a marker of renal dysfunction } \\
\text { (cystatin C) before and up to } 72 \mathrm{~h} \text { after a marathon race in a } \\
\text { large cohort of otherwise healthy individuals. }\end{array}$ & Marathon & 102 & $42 \pm 9$ & Blood & $\begin{array}{l}\text { One week before, } \\
\text { immediately, } 24 \text { and } \\
72 \mathrm{~h} \text { after. }\end{array}$ & $\begin{array}{l}\uparrow I L-6 \text { and TNF- } \alpha \text { only immediately and } \\
24 \mathrm{~h} \text { and IL-10 at all periods after the } \\
\text { running. }\end{array}$ \\
\hline
\end{tabular}


TABLE 2 | Continued

\begin{tabular}{|c|c|c|c|c|c|c|c|}
\hline Authors & Objective & Distance & $\begin{array}{l}\text { No of } \\
\text { participant }\end{array}$ & Age & Sample & Measure points" & Findings \\
\hline Passos et al. (2019) & $\begin{array}{l}\text { The present study was to investigate the association between } \\
\text { quantity of macronutrient and micronutrient daily intake and } \\
\text { inflammation induced by long-distance exercise. }\end{array}$ & Marathon & 44 & $41 \pm 1$ & Blood & $\begin{array}{l}24 \mathrm{~h} \text { before, } \\
\text { immediately, } 24 \text { and } \\
48 \mathrm{~h} \text { after the running. }\end{array}$ & $\begin{array}{l}\uparrow I L-6, I L-1 \beta, I L-8 \text { and IL-10 only } \\
\text { immediately and then the values returned } \\
\text { to baseline. } \leftrightarrow \mathrm{IL}-12 \mathrm{p} 70 \text { and TNF- } \alpha \text { at all } \\
\text { periods after the running. }\end{array}$ \\
\hline Yargic et al. (2019) & $\begin{array}{l}\text { This study is to determine serum levels of these molecules in } \\
\text { runners after a long-distance trail run. }\end{array}$ & $35 \mathrm{~km}$ & 37 & $38 \pm 10$ & Blood & $\begin{array}{l}24 \mathrm{~h} \text { before and } \\
\text { immediately after. }\end{array}$ & $\uparrow$ IL-6, IL-15 and HSP72 \\
\hline $\begin{array}{l}\text { Mastaloudis et al. } \\
\text { (2004) }\end{array}$ & $\begin{array}{l}\text { The present study was to determine whether exercise-induced } \\
\text { lipid peroxidation and inflammation could be alleviated by } 6 \\
\text { weeks of prior supple-mentation with vitamins } E \text { and } C \text { in } \\
\text { recreationally trained women and men participating in an } \\
\text { ultramarathon run. }\end{array}$ & $50 \mathrm{~km}$ & 22 & $39 \pm 2$ & Blood & $\begin{array}{l}1 \mathrm{~h} \text { before, immediately, } \\
24,48 \text { and } 72 \mathrm{~h} \text { after the } \\
\text { running. }\end{array}$ & $\begin{array}{l}\uparrow I L-6 \text { only immediately and then the } \\
\text { values returned to baseline. }\end{array}$ \\
\hline Sansoni et al. (2017) & $\begin{array}{l}\text { This study was to investigate and characterize the metabolic } \\
\text { profile (in terms of hormones involved in energy metabolism), } \\
\text { the metabolic inflammatory profile (in terms of adipokines), and } \\
\text { the bone metabolism by comparing the OC-mediated } \\
\text { response in experienced MUM runners, before and after a } \\
\text { competition, with that of control subjects with a low PA profile. }\end{array}$ & $65 \mathrm{~km}$ & 17 & $38 \pm 7$ & Blood & $\begin{array}{l}1 \mathrm{~h} \text { before and } \\
\text { immediately after the } \\
\text { running. }\end{array}$ & $\uparrow$ Visfatin and Resistin. $\downarrow$ Leptin \\
\hline Miles et al. (2006) & $\begin{array}{l}\text { This investigation was to determine whether attenuation of the } \\
\text { IL-6 response to strenuous endurance exercise associated } \\
\text { with exercise-induced muscle damage occurs in higher } \\
\text { compared to lower ad libitum intake of carbohydrate. }\end{array}$ & $35,2 \mathrm{~km}$ & 32 & $\begin{array}{l}\text { Low } \mathrm{CHO} \text { : } \\
42 \pm 15 \\
\text { high } \mathrm{CHO} \text { : } \\
33 \pm 10\end{array}$ & Blood & $\begin{array}{l}1 \mathrm{~h} \text { before, immediately, } \\
4 \text { and } 24 \mathrm{~h} \text { after the } \\
\text { running. }\end{array}$ & $\begin{array}{l}\text { low } \mathrm{CHO} \text { and high } \mathrm{CHO}: \uparrow \mathrm{IL}-6 \text { only } \\
\text { immediately and } 24 \mathrm{~h} \text {, then the values } \\
\text { returned to baseline. }\end{array}$ \\
\hline Santos et al. (2013a) & $\begin{array}{l}\text { This study was to investigate the changes in lymphocyte and } \\
\text { neutrophil selected functions before and after a marathon race. }\end{array}$ & Marathon & 15 & $35 \pm 3$ & Blood & $\begin{array}{l}3-7 \text { days before and } \\
\text { immediately after the } \\
\text { running. }\end{array}$ & $\uparrow$ IL-6 and IL-1ra; $\leftrightarrow$ TNF- $\alpha$ \\
\hline Gill et al. (2015b) & $\begin{array}{l}\text { The study aimed to determine the circulatory endotoxin } \\
\text { concentration and cytokine profile of ultra-endurance runners } \\
\text { (UER, } n=19 \text { ) and a control group (CON, } n=12 \text { ) during a five } \\
\text { stage } 230 \mathrm{~km} \text { ultra-marathon. }\end{array}$ & $230 \mathrm{~km}$ & 19 & $\begin{array}{l}\mathrm{H}: 41 \pm 8 \\
\mathrm{M}: 49 \pm 4\end{array}$ & Blood & $\begin{array}{l}1 \mathrm{~h} \text { before and } \\
\text { immediately after the } \\
\text { running. }\end{array}$ & $\begin{array}{l}\uparrow \text { IL-6, IL-1ra, IL-1 } 1 \beta, \text { IL-10, TNF- } \alpha \text { and } \\
\text { IFN- } \gamma\end{array}$ \\
\hline $\begin{array}{l}\text { Díaz-Castro et al. } \\
\text { (2012) }\end{array}$ & $\begin{array}{l}\text { The present study was to determine for the first time and } \\
\text { simultaneously whether oral CoQ10 supplementation may be } \\
\text { efficient ameliorating the oxidative stress and pro-inflammatory } \\
\text { effects induced by the strenuous exercise. }\end{array}$ & $50 \mathrm{~km}$ & 10 & $39 \pm 2$ & Blood & $\begin{array}{l}\text { Immediately before and } \\
\text { immediately after the } \\
\text { running. }\end{array}$ & $\uparrow$ IL-6, IL-1ra and TNF- $\alpha$ \\
\hline Nieman et al. (2001) & $\begin{array}{l}\text { This study was to investigate the influence of carbohydrate, } \\
\text { gender, and age on cytokine changes in a large group of } \\
\text { runners after two competitive marathon races. }\end{array}$ & Marathon & 50 & $42 \pm 1$ & Blood & $\begin{array}{l}\text { Immediately before and } \\
\text { immediately and } 1,5 \mathrm{~h} \\
\text { after the running. }\end{array}$ & $\begin{array}{l}\uparrow \text { IL-6, IL-1ra, IL-1 } \beta, \text { IL-10 and TNF- } \alpha \text { at all } \\
\text { periods after the running. }\end{array}$ \\
\hline Skinner et al. (2021) & $\begin{array}{l}\text { This study was to describe and compare the effects of a trail } \\
(40 \mathrm{~km}) \text { race and an ultra-trail }(171 \mathrm{~km}) \text { race on leukocyte } \\
\text { concentrations and cytokine profiles. }\end{array}$ & $\begin{array}{l}40 \mathrm{~km} \text { and } \\
171 \mathrm{~km}\end{array}$ & $\begin{array}{l}40 \mathrm{~km}: 11 \\
\text { and } 171 \mathrm{~km}: \\
12\end{array}$ & $\begin{array}{l}40 \mathrm{~km}: 37 \pm \\
9 ; 171 \mathrm{~km}: \\
38 \pm 6\end{array}$ & Blood & $\begin{array}{l}\text { Immediately before and } \\
\text { immediately after the } \\
\text { running. }\end{array}$ & 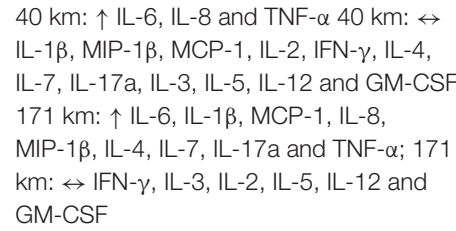 \\
\hline
\end{tabular}




\begin{tabular}{|c|c|c|c|c|c|c|c|}
\hline Authors & Objective & Distance & $\begin{array}{l}\text { No of } \\
\text { participant }\end{array}$ & Age & Sample & Measure points" & Findings \\
\hline Larsen et al. (2020) & $\begin{array}{l}\text { Acute and adaptive changes in systemic markers of oxidatively } \\
\text { generated nucleic acid modifications [i.e., } \\
\text { 8-oxo-7,8-dihydro-2'-deoxyguanosine (8-oxodG) and } \\
\text { 8-oxo-7,8-dihydroguanosine (8-oxoGuo)] as well as } \\
\text { inflammatory cytokines (i.e., C-reactive protein, interleukin-6, } \\
\text { interleukin-10, and tumor necrosis factor alpha), a liver } \\
\text { hormone [i.e., fibroblast growth factor } 21 \text { (FGF21)], and bone } \\
\text { metabolism markers (sclerostin, osteocalcin, C-terminal } \\
\text { telopeptide, and N-terminal propeptide of type } 1 \text { procollagen) } \\
\text { were investigated following a marathon in } 20 \text { study } \\
\text { participants. }\end{array}$ & Marathon & 20 & 29 [24-37] & Blood & $\begin{array}{l}3-7 \text { days before and } \\
\text { immediately after the } \\
\text { running. }\end{array}$ & $\uparrow$ IL-6, IL-10 and TNF- $\alpha$ \\
\hline $\begin{array}{l}\text { Donnikov et al. } \\
\text { (2009) }\end{array}$ & $\begin{array}{l}\text { We studied changes in the levels of IL-6, LIF, and SCF during } \\
\text { long exercise. }\end{array}$ & $51-81 \mathrm{~km}$ & 6 & & Blood & $\begin{array}{l}24 \mathrm{~h} \text { before and } \\
\text { immediately after the } \\
\text { running. }\end{array}$ & $\uparrow I L-6$ \\
\hline $\begin{array}{l}\text { Tavares-Silva et al. } \\
\text { (2021) }\end{array}$ & $\begin{array}{l}\text { Was to verify the effects of probiotic supplementation on } \\
\text { cytokine production by monocytes and infections in the upper } \\
\text { respiratory tract after an acute strenuous exercise. }\end{array}$ & Marathon & 7 & $38 \pm 3$ & Blood & $\begin{array}{l}24 \mathrm{~h} \text { before, immediately } \\
\text { and } 1 \mathrm{~h} \text { after the } \\
\text { running. }\end{array}$ & $\begin{array}{l}\uparrow I \mathrm{IL}-10 \text { only immediately and TNF- } \alpha \text { at all } \\
\text { periods after the running. } \leftrightarrow \mathrm{IL}-2 \text { and IL-4 } \\
\text { at all periods after the running. }\end{array}$ \\
\hline $\begin{array}{l}\text { Ostrowski et al. } \\
\text { (1998) }\end{array}$ & $\begin{array}{l}\text { Was performed to test the hypothesis that the cytokine } \\
\text { response is locally produced in response to mechanically } \\
\text { damaged myofibres or disrupted connective tissue in the } \\
\text { muscle, and that a local cytokine response initiates the } \\
\text { systemic inflammatory response. }\end{array}$ & Marathon & 16 & $30 \pm 1$ & Blood & $\begin{array}{l}1 \text { week before, } \\
\text { immediately and } 2 \mathrm{~h} \\
\text { after the running. }\end{array}$ & $\begin{array}{l}\uparrow I L-6, I L-1 \text { ra and TNF- } \alpha \text { at all periods after } \\
\text { the running and IL-1 } 1 \beta \text { only immediately, } \\
\text { then the values returned to baseline. }\end{array}$ \\
\hline Bekos et al. (2019) & $\begin{array}{l}\text { This study was to investigate the incidence of EIB in } \\
\text { non-asthmatic non-professional runners and to study the } \\
\text { association of EIB and changes in cytokine concentrations, } \\
\text { skin or core temperature. }\end{array}$ & $\begin{array}{l}\text { Half- } \\
\text { marathon } \\
(\mathrm{HM}) \text { and } \\
\text { Marathon } \\
\text { (Ma) }\end{array}$ & $\begin{array}{l}\text { HM: 36; Ma: } \\
34\end{array}$ & $\begin{array}{l}\mathrm{HM}: 36 \pm 7 \\
\mathrm{Ma}: 36 \pm 7\end{array}$ & Blood & $\begin{array}{l}24 \mathrm{~h} \text { before and } \\
\text { immediately after the } \\
\text { running. }\end{array}$ & HM and Ma: $\uparrow$ HSP70 and HSP27 \\
\hline Siegel et al. (2007) & $\begin{array}{l}\text { Exercise-associated hyponatremia }(\mathrm{EAH}) \text {, as defined by a } \\
\text { blood sodium concentration }[\mathrm{Na}+]<135 \mathrm{mmol} / \mathrm{L} \text {, may lead to } \\
\text { hypotonic encephalopathy with fatal cerebral edema. } \\
\text { Understanding the pathogenetic role of antidiuresis may lead } \\
\text { to improved strategies for prevention and treatment. }\end{array}$ & Marathon & 33 & $49 \pm 10$ & Blood & $\begin{array}{l}24 \mathrm{~h} \text { before, } 2 \text { and } 24 \mathrm{~h} \\
\text { after the running. }\end{array}$ & $\begin{array}{l}\uparrow \mathrm{IL}-6 \text { only } 2 \mathrm{~h} \text { and then the values } \\
\text { returned to baseline. }\end{array}$ \\
\hline Nieman et al. (2003) & $\begin{array}{l}\text { Changes in immune and oxidative stress parameters were } \\
\text { measured in ultramarathon runners competing in the 160-km } \\
\text { Western States Endurance Run. }\end{array}$ & $160 \mathrm{~km}$ & 45 & $46 \pm 1$ & Blood & $\begin{array}{l}24 \mathrm{~h} \text { before and } \\
\text { immediately after the } \\
\text { running. }\end{array}$ & 个 IL-6, IL-1ra, IL-8 and IL-10 \\
\hline Zimmer et al. (2016) & $\begin{array}{l}\text { Investigates the short-term effects of a half marathon on } \\
\text { immune cell proportions, pro-inflammatory cytokine levels, and } \\
\text { recovery behavior of patients with breast cancer in the after } \\
\text { race compared to healthy controls. }\end{array}$ & $\begin{array}{l}\text { Half- } \\
\text { marathon }\end{array}$ & 9 & $47 \pm 5$ & Blood & $\begin{array}{l}\text { Immediately before, } \\
\text { immediately and } 24 \mathrm{~h} \\
\text { after the running. }\end{array}$ & $\begin{array}{l}\uparrow \text { IL- } 6 \text { only immediately and TNF- } \alpha \text { only } \\
\text { immediately and then the values } \\
\text { decreased from the baseline. }\end{array}$ \\
\hline $\begin{array}{l}\text { Reihmane et al. } \\
\text { (2013) }\end{array}$ & $\begin{array}{l}\text { To test whether there were relations between endurance } \\
\text { exercise-induced changes in the afore-mentioned mediators. }\end{array}$ & $\begin{array}{l}\text { Half- } \\
\text { marathon } \\
(\mathrm{HM}) \text { and } \\
\text { Marathon } \\
\text { (Ma) }\end{array}$ & $\begin{array}{l}\text { HM: } 22 \text { and } \\
\text { Ma: } 18\end{array}$ & $\begin{array}{l}\text { HM: } 26 \pm 5 \\
\text { Ma: } 27 \pm 5\end{array}$ & Blood & $\begin{array}{l}2 \text { days before, } \\
\text { immediately and } 28 \mathrm{~h} \\
\text { after the running. }\end{array}$ & $\begin{array}{l}\mathrm{HM}: \leftrightarrow \mathrm{IL}-6 \text { and TNF- } \alpha \text {; Ma: } \uparrow \mathrm{IL}-6 \text { only } \\
\text { immediately and then the values returned } \\
\text { to baseline. }\end{array}$ \\
\hline
\end{tabular}




\begin{tabular}{|c|c|c|c|c|c|c|c|}
\hline Authors & Objective & Distance & $\begin{array}{l}\text { No of } \\
\text { participant }\end{array}$ & Age & Sample & Measure points" & Findings \\
\hline Wilhelm et al. (2014) & $\begin{array}{l}\text { We measured SAPWD as a surrogate for atrial conduction and } \\
\text { remodeling in healthy runners before and after a strenuous } \\
\text { mountain marathon. }\end{array}$ & Marathon & 10 & $34 \pm 4$ & Blood & $\begin{array}{l}24 \mathrm{~h} \text { before, immediately } \\
\text { and } 24 \mathrm{~h} \text { after the } \\
\text { running. }\end{array}$ & $\begin{array}{l}\uparrow I L-6 \text { and TNF- } \alpha \text { only immediately and } \\
\text { then the values returned to baseline. }\end{array}$ \\
\hline Chiu et al. (2013) & $\begin{array}{l}\text { To measure the magnitude of serological response in } \\
\text { ultra-mara-thon runners, compare the liver function tests, } \\
\text { muscle damage markers and oxidative stress cytokines of } \\
\text { athletes. }\end{array}$ & $100 \mathrm{~km}$ & 18 & $46 \pm 9$ & Blood & $\begin{array}{l}1 \text { week before, } \\
\text { immediately and } 24 \mathrm{~h} \\
\text { after the running. }\end{array}$ & $\begin{array}{l}\uparrow I L-6 \text { and TNF- } \alpha \text { all periods after the } \\
\text { running. }\end{array}$ \\
\hline Pistilli et al. (2002) & $\begin{array}{l}\text { To examine the effects of a competitive marathon race on } \\
\text { immune alterations in a relatively large group of younger and } \\
\text { older runners. }\end{array}$ & Marathon & $\begin{array}{l}\text { Older: } 23 \\
\text { Young: } 75\end{array}$ & $\begin{array}{l}\text { Older: } 57 \\
\text { Young: } 37\end{array}$ & Blood & $\begin{array}{l}\text { Before, immediately and } \\
1,5 \mathrm{~h} \text { after the running. }\end{array}$ & $\begin{array}{l}\text { Older and Young: } \uparrow \mathrm{IL}-6, \mathrm{IL}-1 \mathrm{ra}, \mathrm{LL}-8 \text { and } \\
\mathrm{IL}-10 \text { all periods after the running. }\end{array}$ \\
\hline Henson et al. (2004) & $\begin{array}{l}\text { To verify the influence of } 6 \% \text { carbohydrate intake and age on } \\
\text { PHA-induced lymphocyte proliferation and cytokine } \\
\text { production in vitro. }\end{array}$ & Marathon & 25 & $41 \pm 2$ & Blood & $\begin{array}{l}\text { Before, immediately and } \\
1,5 \mathrm{~h} \text { after the running. }\end{array}$ & $\downarrow$ IFN- $\gamma$ all periods after the running. \\
\hline Nieman et al. (2002) & $\begin{array}{l}\text { To measure the influence of vitamin C compared with placebo } \\
\text { supplementation on oxidative and immune changes in } \\
\text { ultramarathoners competing in an ultramarathon race. }\end{array}$ & $80 \mathrm{~km}$ & 13 & $45 \pm 2$ & Blood & $\begin{array}{l}\text { Before and immediately } \\
\text { after the running. }\end{array}$ & $\begin{array}{l}\uparrow \text { IL-6, IL-1ra, IL-8 and IL-10; } \downarrow \text { IL-2 and } \\
\text { IFN- } \gamma\end{array}$ \\
\hline Nickel et al. (2012) & $\begin{array}{l}\text { To assess exercise-induced alterations of circulating dendritic } \\
\text { cell (DC) sub-populations and toll-like receptor (TLR) } \\
\text { expression after marathon running. }\end{array}$ & Marathon & 16 & $\begin{array}{l}E: 40 \pm 7 \\
N E: 40 \pm 6\end{array}$ & Blood & $\begin{array}{l}2-5 \text { days before, } \\
\text { immediately and } 24 \mathrm{~h} \\
\text { after the running. }\end{array}$ & $\begin{array}{l}\text { E and NE: } \uparrow I L-6 \text { all periods after the } \\
\text { running and IL-10 only immediately and } \\
\text { TNF- } \alpha \text { only } 24 \mathrm{~h} \text {. }\end{array}$ \\
\hline Nieman et al. (2005) & $\begin{array}{l}\text { Test these relationships, reasoning that elevations in plasma } \\
\text { cytokines and significant muscle damage would occur within } \\
\text { the first few hours of this high altitude race in the Sierra } \\
\text { Nevada Mountains, and then be maintained for } 20-30 \mathrm{~h} \text { when } \\
\text { correlations with CPK could be tested at the end of the race. }\end{array}$ & $160 \mathrm{~km}$ & 60 & $45 \pm 1$ & Blood & $\begin{array}{l}\text { The morning before the } \\
\text { running and immediately } \\
\text { after the running. }\end{array}$ & $\begin{array}{l}\uparrow \text { IL-6, IL-1ra, IL-8, IL-10, MCP-1, MIP-1 } 1 \beta \\
\text { and G-CSF }\end{array}$ \\
\hline Toft et al. (2000) & $\begin{array}{l}\text { Was to investigate whether fish oil supplementation was able } \\
\text { to modulate the acute-phase response to strenuous exercise. }\end{array}$ & Marathon & 10 & 28 [24-43] & Blood & $\begin{array}{l}\text { One week before, } \\
\text { immediately, } 1.5 \text {, and } \\
3 \mathrm{~h} \text { after the running. }\end{array}$ & $\begin{array}{l}\uparrow I L-6, I L-1 \text { ra and TNF- } \alpha \text { all periods after } \\
\text { the running. } \leftrightarrow \text { TGF } \beta \text { all periods after the } \\
\text { running. }\end{array}$ \\
\hline Bachi et al. (2015) & $\begin{array}{l}\text { To investigate how physical and psychological changes } \\
\text { induced in mara-thon runners by training and by the race can } \\
\text { affect mood states, hormones and cytokines. }\end{array}$ & Marathon & 20 & $35 \pm 9$ & Blood & $\begin{array}{l}24 \mathrm{~h} \text { before, } \\
\text { immediately, and } 72 \mathrm{~h} \\
\text { after the running. }\end{array}$ & $\begin{array}{l}\uparrow \mathrm{IL}-10 \text { only immediately and then the } \\
\text { values returned to baseline. } \leftrightarrow \mathrm{IL}-8 \text { only } \\
\text { immediately and then the values } \\
\text { decreased from the baseline. }\end{array}$ \\
\hline Scherr et al. (2012) & $\begin{array}{l}\text { To determine whether ingestion of NAB polyphenols for } 3 \\
\text { weeks before and } 2 \text { weeks after a marathon would attenuate } \\
\text { postrace inflammation and decrease URTI incidence. }\end{array}$ & Marathon & 63 & $42[35-49]$ & Blood & $\begin{array}{l}1 \text { week before, } \\
\text { immediately, } 24 \text { and } \\
72 \mathrm{~h} \text { after the running. }\end{array}$ & $\begin{array}{l}\uparrow \mathrm{IL}-6 \text { only immediately and then the } \\
\text { values returned to baseline. }\end{array}$ \\
\hline $\begin{array}{l}\text { Ostrowski et al. } \\
\text { (1999) }\end{array}$ & $\begin{array}{l}\text { Investigates to what extent and by which time course } \\
\text { prolonged strenuous exercise influences the plasma } \\
\text { concentration of pro-inflammatory and inflammation } \\
\text { responsive cytokines as well as cytokine inhibitors and } \\
\text { anti-inflammatory cytokines. }\end{array}$ & Marathon & 10 & 28 [24-37] & Blood & $\begin{array}{l}1 \text { week before, } \\
\text { immediately and every } \\
30 \text { min until } 4 \mathrm{~h} \text { after the } \\
\text { running. }\end{array}$ & $\begin{array}{l}\uparrow I L-6 \text { and IL-1ra all periods after the } \\
\text { running, IL-1 } 1 \beta \text { only immediately and } \\
30 \text { min and TNF- } \alpha \text { only immediately and } \\
\text { until } 3 \mathrm{~h} \text { after the running, then the values } \\
\text { returned to baseline. }\end{array}$ \\
\hline $\begin{array}{l}\text { Batatinha et al. } \\
\text { (2020) }\end{array}$ & $\begin{array}{l}\text { To evaluate the alterations caused by a marathon in the } \\
\text { lymphocyte population and function, and the effects of } \\
\text { probiotics in this process. }\end{array}$ & Marathon & 13 & $40 \pm 7$ & Blood & $\begin{array}{l}24 \mathrm{~h} \text { before and } 1 \mathrm{~h} \text { after } \\
\text { the running. }\end{array}$ & $\begin{array}{l}\uparrow \text { IL-6, IL-8 and IL-10; } \leftrightarrow \text { IL-2, IL-4, IL-1 } \beta \text {, } \\
\text { TNF- } \alpha \text {, IFN- } \gamma \text { and IL- } 15\end{array}$ \\
\hline $\begin{array}{l}\text { Benedetti et al. } \\
\text { (2021) }\end{array}$ & $\begin{array}{l}\text { Monitored for the first time in ultramarathon athletes running } \\
\text { the } 24-\mathrm{h} \text { competition, an extremely demanding race in terms } \\
\text { of muscular and physiological exertion. }\end{array}$ & $99-218 \mathrm{~km}$ & 22 & $42 \pm 11$ & Blood & $\begin{array}{l}3 \mathrm{~h} \text { before and } \\
\text { immediately after the } \\
\text { running. }\end{array}$ & $\uparrow I L-6$ \\
\hline
\end{tabular}
(then be maintained for 20-30 h when

the her physical and psychogical changes

To determine whether ingestion of $\mathrm{NAB}$ polyphenols for 3 weeks before and 2 weeks after a marathon would attenuate 
increase in its concentration after the half-marathon (Gaggini et al., 2021). The sTNFRII and sIL-6R were evaluated in a study (Neidhart et al., 2000), there was no change after marathon. Three studies evaluated the TGF- $\beta$ (Toft et al., 2000; Abbasi et al., 2013; Niemelä et al., 2016) and no significant differences were found after running. The G-CSF was evaluated in seven studies (Suzuki et al., 2000, 2003; Bonsignore et al., 2002; Nieman et al., 2005, 2006, 2007; Shanely et al., 2014). G-CSF concentration increased after running in all studies, regardless of running distance. Eight studies evaluated MCP-1 (Suzuki et al., 2003; Nieman et al., 2005, 2006, 2007; Abbasi et al., 2013; Shanely et al., 2014; Clifford et al., 2017; Skinner et al., 2021) and only in one study there was no change in the concentration of MCP1 (Clifford et al., 2017). Four studies evaluated the MIP-1 $\beta$ (Nieman et al., 2005, 2006, 2007; Skinner et al., 2021) and showed concentration increase. The GM-CSF was evaluated in one study (Skinner et al., 2021) and did not showed alterations. Two studies evaluated HSP72, there was an increase in concentration after running in both studies (Shanely et al., 2014; Yargic et al., 2019). The HSP27 e HSP70 were evaluated in only one study (Bekos et al., 2019). Both showed an increase after the half-marathon and marathon.

\section{Meta-Analysis}

For the meta-analysis, were included the individual and summarized effects of the studies that analyzed the IL-6 $(n=$ $20)$, IL-1ra $(n=10)$, IL-I $\beta(n=7)$, IL-2 $(n=5)$, IL-4 $(n=$ $3)$, IL-8 $(n=13)$, IL-10 $(n=12)$, TNF- $\alpha(n=11)$ and INF-y $(n=6)$. In the analysis of subgroups performed with IL-6 in consideration of half-marathon $(n=2)$, marathon $(n=8)$ and ultra-marathon $(n=10)$, in the pre vs post-running comparison, an increase was observed in all the distances (SMD -6.69; IC 95\%: $-8.14,-5.24 ; p<0.0001$ ) highlighted a regular rise to running distance: half-marathon (SMD -1.36 ; IC $95 \%$ : -1.82 , $-0.89, \mathrm{Ch}^{2}: 0.58$; $\operatorname{tau}^{2}: 0.00 ; p<0.0001$ ), marathon (SMD -6.81 ; IC 95\%: $\left.-9.26,-4.37 ; \mathrm{Ch}^{2}: 481.37 \mathrm{tau}^{2}: 11.88 ; p<0.0001\right)$ and ultra-marathon (SMD-8.00 IC 95\%: $-10.47,-5.53 ; \mathrm{Ch}^{2}: 328.40$; $\left.\operatorname{tau}^{2}: 14.19 ; p<0.0001\right)$. Meta-regression analysis showed no significant regressions on half marathon, marathon and ultramarathon ( $\mathrm{p}=0.864)$ (Figure 4).

An increase in the concentration of IL-1ra (SMD-5.65; IC 95\%:-7.13,-4.17; $p<0.0001$ ), IL-1ra (SMD -0.95; IC 95\%: $-1.39,-0.50 ; p<0.0001$ ), IL-8 (SMD -5.38; IC 95\%: -7.25 ,3.51; $p<0.0001$ ), IL-10 (SMD -32.59; IC 95\%: -45.99,-19.19; $p<0.0001$ ) and TNF- $\alpha$ (SMD -0.83; IC 95\%: $-1.00,-0.67 ; p<$ 0.0001 ). A reduction in the concentration of IL-2 (SMD 57.74; IC 95\%: 37.12, 78.36; $p<0.0001$ ) and INF-y (SMD 1.97; IC 95\%: $0.23,3.71 ; p<0.03$ ) and there was no change in the IL4 (SMD -0.10; IC 95\%: $-0.42,0.23 ; p<0.56$ ). Evidence of heterogeneity and inconsistency was found for IL-1ra $\left(\mathrm{Ch}^{2}=\right.$ 230.31; $\left.\mathrm{Tau}^{2}=5.17 ; \mathrm{I}^{2}=96 \%\right)$, IL-1ra $\left(\mathrm{Ch}^{2}=25.28 ; \mathrm{Tau}^{2}=\right.$ $\left.0.25 ; \mathrm{I}^{2}=76 \%\right), \mathrm{IL}-2\left(\mathrm{Ch}^{2}=374.24 ; \mathrm{Tau}^{2}=464.72 ; \mathrm{I}^{2}=\right.$ 99\%), IL-8 $\left(\mathrm{Ch}^{2}=849.11 ; \mathrm{Tau}^{2}=11.46 ; \mathrm{I}^{2}=99 \%\right), \mathrm{IL}-10\left(\mathrm{Ch}^{2}\right.$ $\left.=550.64 ; \mathrm{Tau}^{2}=5,179.66 ; \mathrm{I}^{2}=96 \%\right)$, TNF- $\alpha\left(\mathrm{Ch}^{2}=274.93\right.$; $\left.\mathrm{Tau}^{2}=2.20 ; \mathrm{I}^{2}=96 \%\right)$ and INF-y $\left(\mathrm{Ch}^{2}=138.99 ; \mathrm{Tau}^{2}=4.38\right.$; $\left.\mathrm{I}^{2}=96 \%\right)$ (Figure 5). 
A

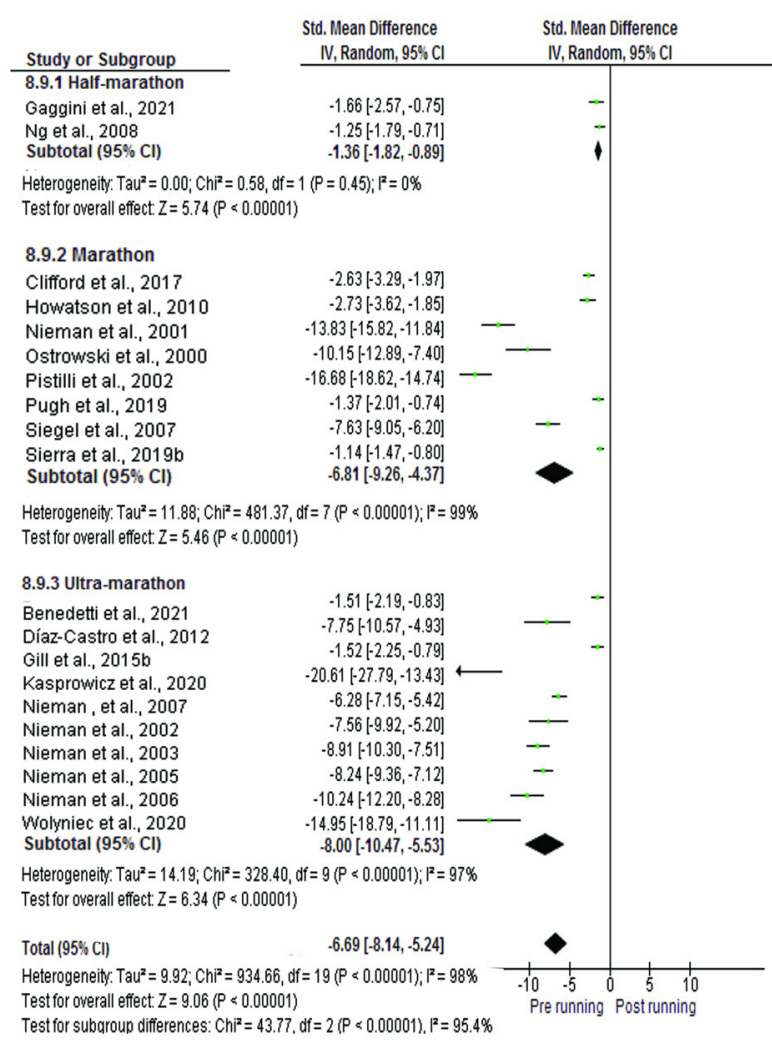

B

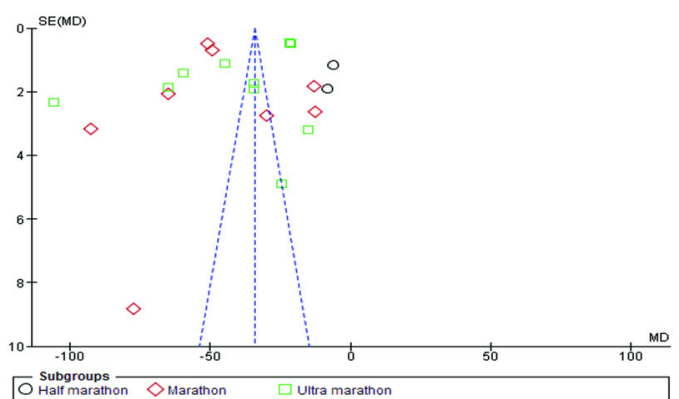

C

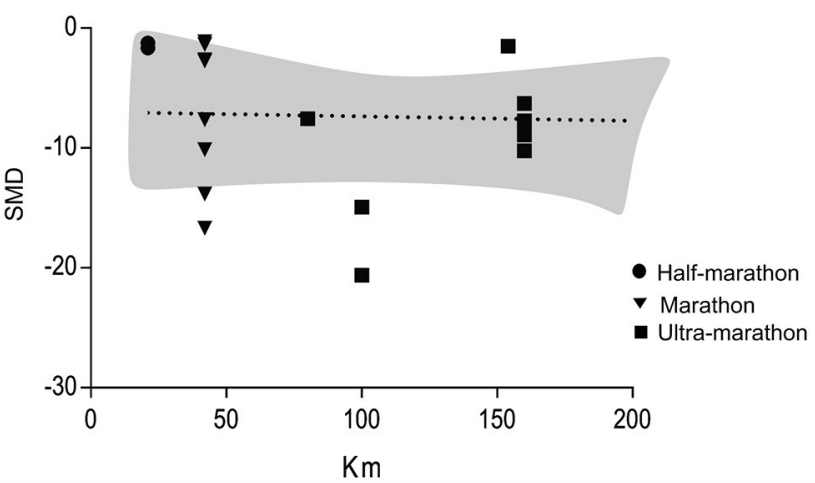

FIGURE 4 | Meta-analysis of half-marathon, marathon, and ultra-marathon. (A) Forest plot, (B) Funnel plot, and (C) meta-regression analyses.

\section{DISCUSSION}

In the current report, we describe changes in impacts of running volume on the concentration of cytokines in halfmarathon, marathon and ultra-marathon. Was verified increase in inflammation status immediately after completing the running. The meta-analysis showed that the running volume variability modulate in the maintenance of homeostasis and cell signaling. On the other hand, the increase in volume does not proportionally increase the concentration of IL-6, IL-1 ra, IL-1 $\beta$, IL- 8, IL-10 and TNF- $\alpha$ after the running. In contrast, few studies evaluated adipokines. Prolonged aerobic exercise exerts a huge impact on metabolism and energy balance, is an exhausting effort for the whole organism and leads to a proinflammatory profile.

Cytokines are important mediators regularizing the immune response, and their enhancement may yield valuable information pertinent to questions like transient post-running immunosuppression, beneficial anti-inflammatory. Although a high increase in cytokine concentration was expected to occur after long-distance running, a key point was if an increase in concentration proportional to running volume would occur. This fact was not confirmed when analyzing the studies that evaluated the concentration of IL- 6 by subgroups: half-marathon, marathon and ultra-marathon (Figure 3). Regardless of if running over $42 \mathrm{~km}$ are more complex, results show that to achieve homeostatic equilibrium, the integrated action of the neuroendocrine and immune systems is necessary (Bachi et al., 2015). The higher serum levels of growth hormone in athletes at rest and the higher production of cytokines without previous stimulus suggests that long distance runners present mechanisms that may be associated with preparing the body to perform prolonged strenuous exercise. Therefore, the inherent vulnerability to exercise induced inflammatory alterations is passible adaptation mechanisms to training (Scherr et al., 2011).

Regardless of whether long-distance running athletes are more prepared, the studies that evaluated the recovery time of IL- 6 showed after $21 \mathrm{~km}$, the less time required to return to baseline conditions. So, several hypotheses have been raised to explain that recovery seems to be more associated with running volume including intensity of exercise or training status (Scherr et al., 2011; Gaggini et al., 2021). However, the results are still controversial. If on the one hand, in the quantification of the concentration of IL-6 after a half-marathon, it was only verified an increase immediately after the running, occurs a return to baseline conditions after the running (Gaggini et al., 2021) or also even 30 minutes (Abbasi et al., 2013). And that pattern was different after marathon, kinetics of serum IL-6 
A

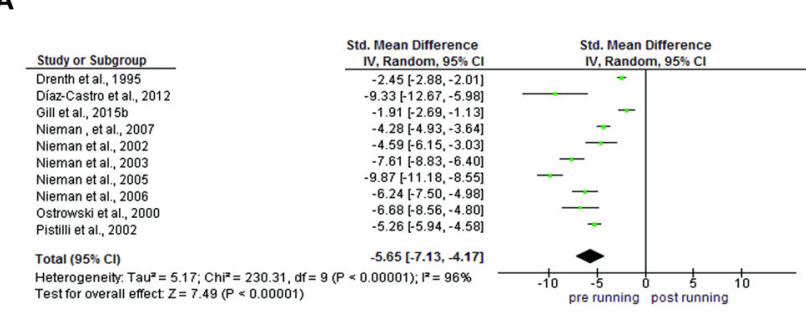

B

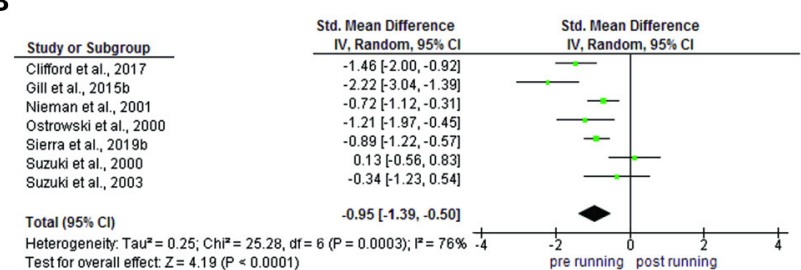

C

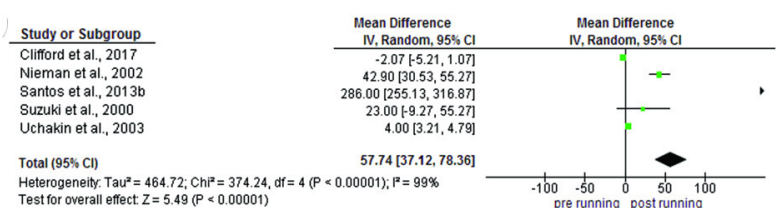

D

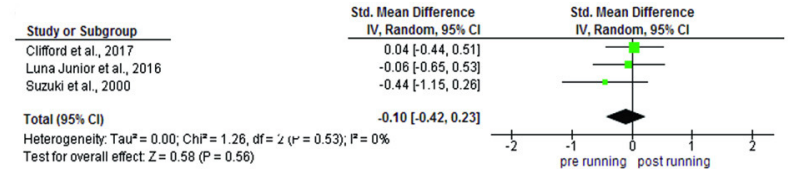

E

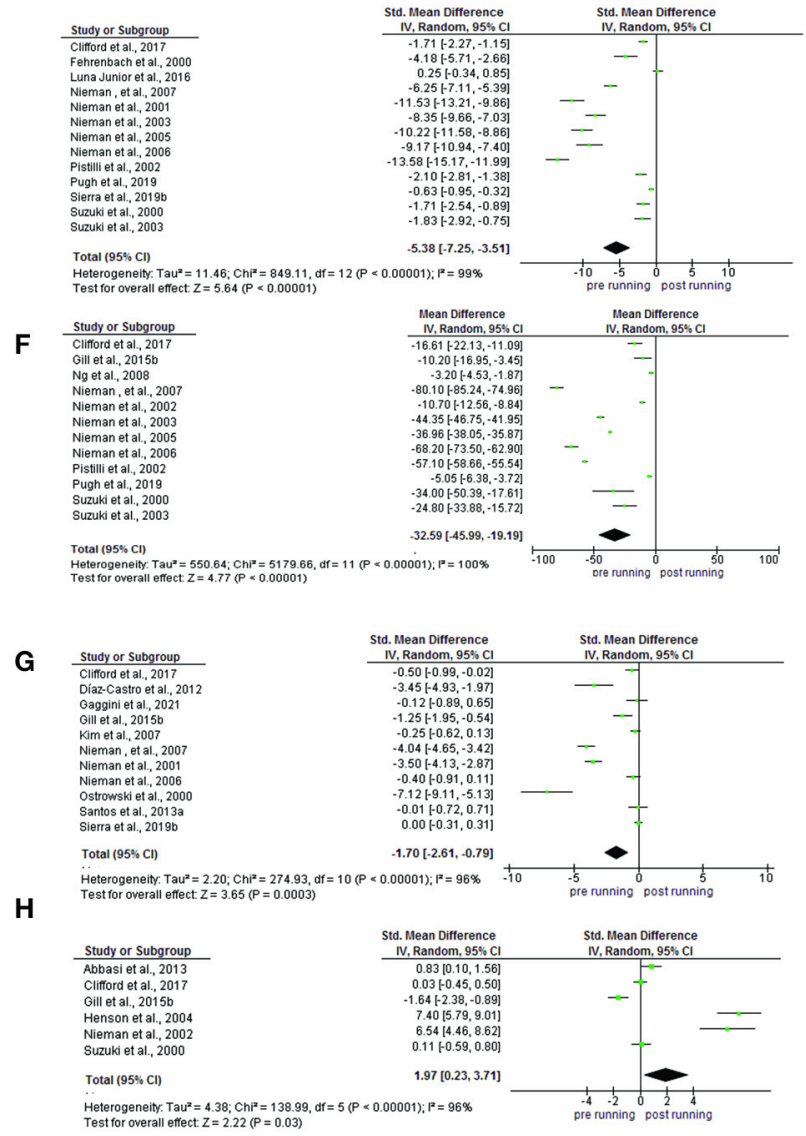

FIGURE 5 | Comparison and effect among cytokines (A) IL-1ra, (B) IL-1 $\beta$, (C) IL-2, (D) IL-4, IL(E)-8, (F) IL-10, (G) TNF- $\alpha$, and (H) INF-y.

concentration prolonged elevation for at least $24 \mathrm{~h}$ (Scherr et al., 2011). Furthermore, the studies that evaluated $100 \mathrm{~km}$ (Chiu et al., 2013) and $50 \mathrm{~km}$ (Mastaloudis et al., 2004) showed baseline conditions in $24 \mathrm{~h}$.

In accordance with the reports of studies, was verified that levels of six cytokines, IL-6, IL-1ra, IL-1 $\beta$, IL-8, IL-10 and TNF- $\alpha$ rose strongly in response to race competition. Unlike IL-2 and INF-y, whom decreased. Post running levels of IL4 , remained near pre running or at no detectable levels. This outcome corroborates with classical studies (Nieman et al., 2001). Reported long- running induced muscle cell metabolic activity and damage appear to be important triggers of macrophage and neutrophil migration and cytokine release (Terra et al., 2012). The low post running levels found in studies as IL-4 may be due to the strong inhibitory effects of IL-10, IL-1ra and IL-6 which together help prevent an overly active systemic inflammation (Suzuki et al., 2000). Several explain about the decrease in the IL-2 and INF-y reported increased lymphocyte proliferation (Santos et al., 2013b). Leukocyte function is modulated by different pathways such as proliferation control, cytokine and anti-inflammatory mediator, generation, adhesion molecule expression, and cell death (Akhtar Khan, 2010).
Physical activity increases myokine levels. The IL-6 was observed on a large scale in 62 studies. IL-6 plays a positive role in glucose metabolism (Glund and Krook, 2007; Shoghi et al., 2008; Pedersen, 2011), increasing its uptake by myocytes (Carey et al., 2006), and elevating insulin-stimulated glycogen synthesis in skeletal muscle (Weigert et al., 2005). Intramuscular concentration of IL-6 mRNA (Keller et al., 2001) and protein release (Steensberg et al., 2001) are exacerbated when intramuscular glycogen is compromised, suggesting that IL-6 functions as an energy sensor (Pedersen and Febbraio, 2008). The level of IL-6 was shown to increase exponentially proportional to the exercise duration and the amount of muscle mass involved in the exercise (Pedersen, 2016). Running, which involves several large muscle groups, is the mode of exercise where most marked increases in plasma IL-6 have been observed (Pedersen and Febbraio, 2008). Exercise duration is the most important factor in determining post-exercise plasma IL-6 amplitude (Reihmane et al., 2013). In this perspective, plasma IL-6 can increase up to 40 times after a marathon (Reihmane et al., 2013; Santos et al., 2016; Larsen et al., 2020; Skinner et al., 2021), with the elevation being equivalent to that observed in negative health status (Skinner et al., 2021). 
The Inflammatory response is associated with the proinflammatory cytokine storm (Smith et al., 2020). This process is due in part to the activation of M1 type macrophages, which have characteristic proinflammatory such as IL-1 $\beta$ (Bent et al., 2018). This important cytokine is one of the mediators of inflammation and is involved in several cellular activities, including cell proliferation, differentiation, and apoptosis (Conti et al., 2002; Bent et al., 2018). The present review identified variability in the effects of running volume on IL-1 $\beta$ levels. The majority demonstrated significant increase in long-distance runners. Thus, the increased plasma concentrations of IL- $1 \beta$ after the Prolonged aerobic exercise could reflect exercise-mediated inflammasome NLRP3 pathway activation during long-running caused by the extreme effort. Oxidized hemoglobin, a hemolysis related product, has been identified as a potent trigger of NLRP3 activation and IL-1 $\beta$ production (Skinner et al., 2021).

Interleukins 2, 4, and 8 actively participate in the structure of the immune system, in the maturation of $\mathrm{T}$ lymphocytes, activation of macrophages via alternative pathways and migration of neutrophils, respectively. Few studies have evaluated the responses caused by running volume in IL-2 and 4. Only two studies identified a reduction in IL-2 and INF-y levels in marathon runners, studies showed that low levels of this protein are associated with impairment of immunological memory and character pathologies inflammatory including rheumatoid arthritis (Arenas-Ramirez et al., 2015; Wu et al., 2020). In a previous study, was reported a significant reduction of IL-2 and INF-y production in runners at the completion of an $80 \mathrm{~km}$ ultra-marathon (Nieman et al., 2002). In addition, other exhaustive aerobic exercise depression of IL-2 and INF-y $1 \mathrm{~h}$ after the event (Weinstock et al., 1997; Nieman et al., 2005) and after and $1.5 \mathrm{~h}$ after completion of the marathon race (Henson et al., 2004). These findings are consistent with our data showing a significant decline in both induced production of INF-y (unadjusted and adjusted per T-cell) and IL-2. Additionally, in IL-4 levels, no differences were found in runners. Inhibitory cytokines, namely IL-4 have been shown to upregulate IL-1ra production and downregulate IL- $1 \beta$ and TNF- $\alpha$ (Suzuki et al., 2000). Cortisol concentration also increased after the race, and it has been shown that it can also inhibit the production of several cytokines (Nieman et al., 2001).

Most of the thirteen studies used in our systematic review demonstrated high levels of IL- 8 in the blood of half-marathon, marathon, and $160 \mathrm{~km}$ runners. Studies demonstrate the effective participation of physical activity and physical exercise, especially the aerobic emphasis on the modulation of this myokine (Barbalho et al., 2020). IL-8 is a classical proinflammatory cytokine, it was originally identified as a chemoattractant factor for neutrophils (dos Santos et al., 2020). Beyond its proinflammatory role, IL-8 also presents a prominent angiogenic function and, as mentioned, is considered a myokine (dos Santos et al., 2020). According to the literature, the increased IL-8 levels in response to muscle damage induced by a physical exercise session are mainly associated with the regulation of muscle angiogenesis by its binding to the CXC receptor 2 (CXCR2) expressed in microvascular endothelial cells in order to improve muscle regeneration (Frydelund-Larsen et al., 2007).
The IL-10 and TNF- $\alpha$ carry out antagonistic immune responses. Biologically, IL-10 works by deactivating macrophages to produce inhibitory effects on Natural Killer (NK) cells and $\mathrm{T}$ lymphocytes, moreover, to playing a fundamental antiinflammatory role (Saraiva and O'Garra, 2010). Our data reveal that different running volumes significantly elevated blood and urine IL-10 levels. Pedersen (2017) demonstrated that physical exercise can potentiate IL-10 activity, reducing inflammation that is part of the synthesis of several cardiometabolic pathologies, including type 2 diabetes mellitus and cardiovascular diseases. This points to the possible preventive character of this immunological marker in these conditions (Pedersen, 2017).

On the other hand, TNF- $\alpha$ is identified as one of the considerable cytokines for inflammation in different organisms. Furthermore, it is linked to the emergence and development of different types of cancers (Balkwill, 2009). In the data used in this review, we found a variety of responses within the production of this protein after different running volumes. Furthermore, it is known that acute physical exercises that require high demands of metabolic effort, including ultra-marathon, can promote an increase in this cytokine (Uchida et al., 2014). Results indicate that during a marathon run, the pro-inflammatory markers TNF$\alpha$ are not produced by blood mononuclear cells on the mRNA level to a clinically relevant extent during a marathon running (Bernecker et al., 2013). There is, however, a significant increase in TNF- $\alpha$ in the plasma, suggesting a local production or release from the stressed skeletal muscle tissues of these cytokines. More studies are needed in high running volumes for better understand (Uchida et al., 2014).

Were also observed changes caused by high running volume in leptin, resistin, adiponectin and visfatin levels. Leptin participates in the regulation of food intake, energy balance and reproductive system (Zhang and Chua, 2017). Furthermore, its deficiency in its production is related to the genesis of obesity. Only two studies looked at the possible effects of running volume on the production of this hormone in the blood. Where only, Zaccaria et al. (2002) observed a significant reduction in leptin after $100 \mathrm{~km}$ of running. Several studies with different experimental models demonstrate that aerobic exercise can bring changes in leptin levels, increasing its sensitivity and acting preventively on obesity (Yetgin et al., 2018; Fernandes et al., 2020).

In contrast, high levels of resistin were found in the blood of marathon runners and $100 \mathrm{~km}$ away. This protein is secreted by adipose tissue, immune and epithelial cells in mammals, it has the function of blocking the action of leptin, reducing satiety (Acquarone et al., 2019). Moreover, clinical studies have shown that the increase in resistin after physical exercise is associated with a reduction in fatigue, playing a fundamental role in the reduction of musculoskeletal and joint inflammatory events, common in pathologies such as fibromyalgia, obesity, and high demands for effort physical and running volumes (Bjersing et al., 2013).

Adiponectin's are proteins produced mainly because they play a fundamental role in glycemic and free fatty acid control. In our data, an increase in adiponectin levels in marathon runners was observed only in one study. However, the role of physical 


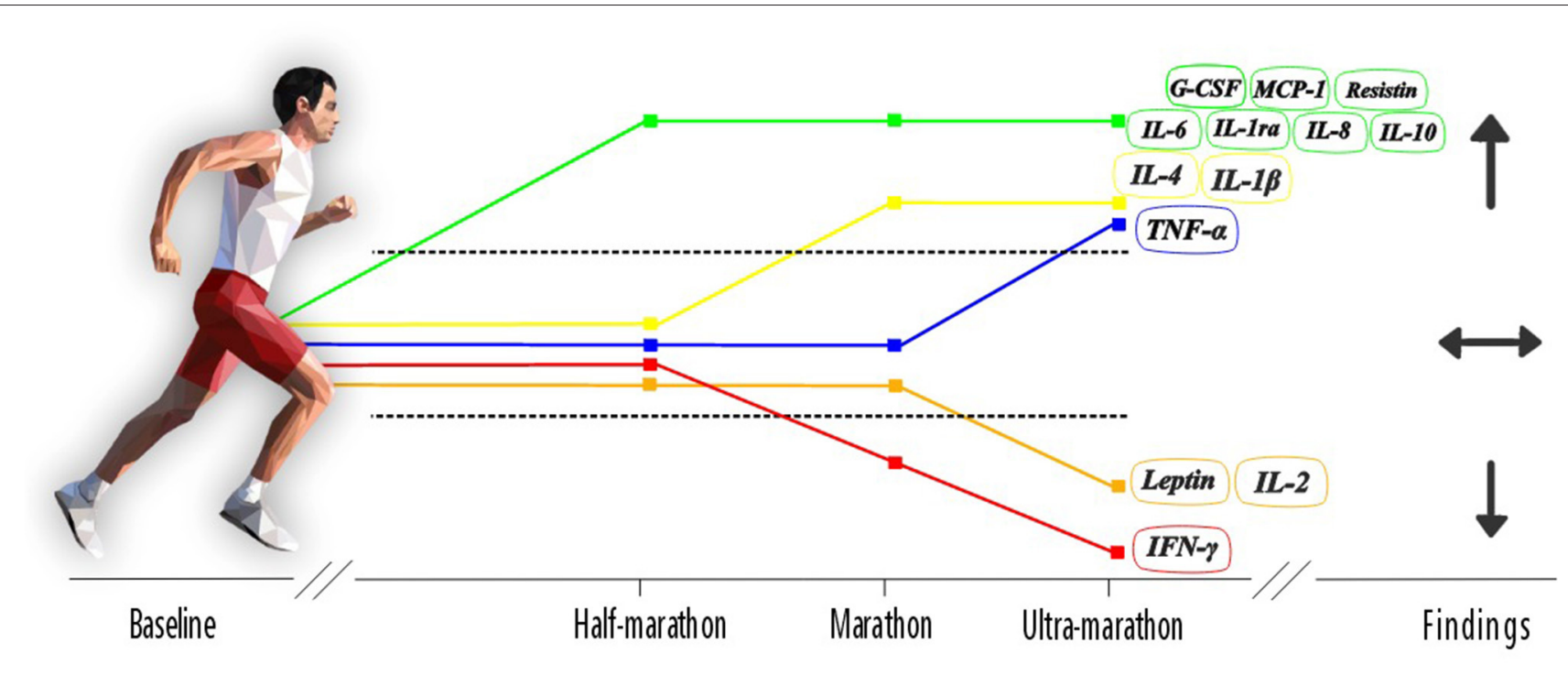

The behavior of plasma cytokine concentration in runs half-marathon, marathon, and ultramarathon. Notes: $m, \ldots, \mathbf{m}, \mathbf{m}$ and $m$ : Post-running only on period immediately after half-marathon, marathon or ultra-marathon; $\uparrow$, Significant increase; $\downarrow$, Significant decrease; $\leftrightarrow$, no change; IL, Interleukin; ILlra, Interleukin-1 Receptor Alfa; TNF- $\alpha$, Tumor Necrosis Factor-Alfa; IFN. $\gamma$, Interferon Gamma; G-CSF, Granulocyte Colony-Stimulating Factor; MCP-1, Monocyte Chemotactic Protein 1; MIP-1 $\beta$, Macrophage Inflammatory Protein 1 Beta. Pngwing. (2021)

FIGURE 6 | Changes in cytokines concentration following long-distance running (Pngwing, 2021).

exercise in different modalities and protocols in the increase of adiponectin's is well established (Li et al., 2019). Finally, visfatin, it is produced by visceral adipose tissue with insulinomimetic activities with systemic and local action. Within the studies that evaluated this biomarker, no significant differences were observed. However, its role associated with physical exercise needs to be elucidated (Jamurtas et al., 2015).

In addition, we also consider other limitations that have been little explored in the research, mainly related to the analysis between sex, ultra-marathon distance and follow-up of 24,48 , and $72 \mathrm{~h}$. Only 1 study discriminated the results differentiating by sex. Although $31 \%$ of studies evaluated 24 -h follow-up, only $3 \%$ was evaluated in ultra-marathon running, of these, 48 and $72-\mathrm{h}$ follow-up was evaluated in 2 and 1 studies, respectively. There was great variability of distance between the ultra-marathon running (51-308 km) generating high amplitude (6:00 to $62: 20 \mathrm{~h}$ ) between the times of conclusion of the races. All these facts, added to the heterogeneity, made it difficult to carry out a quantitative analysis, suggesting the expansion of new studies contemplating these objectives, as well as, differentiating single and multi-day ultra-marathons.

In conclusion, the trans-signaling of cytokines results in inflammation and is therefore linked to high-grade inflammatory. Long-distance running promote an increase in the concentration of IL-6, IL-1ra, IL-1 $\beta$, IL-8, IL-10 and TNF- $\alpha$ and a decrease in the concentration of IL-2 (Figure 6). The effects of an acute bout of prolonged aerobic exercise will protect against chronic systemic inflammation. The time to return to baseline values showed a substantial and dosedependent relationship with run volume. The concentration of IL-6 was robustly studied in long-distance running present in more than $80 \%$ of the selected articles and the marathon running was the most explored. Further studies with adipokines are recommended mainly in ultra-marathons as well, and further investigations related to runner level, age, sex, follow-up, multi-stage ultra-marathons also suggested.

In practical considerations, the ability of a runner to minimize the effects of an acute bout of prolonged aerobic exercise will against chronic systemic inflammation may be identified as one of the determinant factors of performance. The athletes attention must be taken in age regulations, nutrition, training status and race-specific factors (elevation change, such as distance, level of medical assistance, ambient temperatures and type of provisions provided by the race organizers), being able decrease induced physical and physiological distresses and speeding up recovery and rehabilitation from injuries. Long-distance running may have different physiological requirements for ultra-marathon, marathon, and half-marathon. Consequently the strategies of runners provide a challenge for inflammatory process, and there is a general interest in interpret its alterations.

\section{DATA AVAILABILITY STATEMENT}

The raw data supporting the conclusions of this article will be made available by the authors, without undue reservation.

\section{AUTHOR CONTRIBUTIONS}

MA, DS, and RS: conceptualization. MA, DS, EP, and DO: methodology. RS, MS, DP, MA, and DS: writing-original draft. FA, DS, and LV-S: formal analysis. RS, MA, DS, EP, DO, MS, 
and FA: writing-review and editing. All authors contributed to the final version of the manuscript.

\section{FUNDING}

We would like to thank the Coordination for the Improvement of Higher Education Personnel (CAPES, Finance Code 001 and CAPES/PROCAD-2013).

\section{REFERENCES}

Abbasi, A., Fehrenbach, E., Hauth, M., Walter, M., Hudemann, J., Wank, V., et al. (2013). Changes in spontaneous and lps-induced ex vivo cytokine production and mrna expression in male and female athletes following prolonged exhaustive exercise. Exerc. Immunol. Rev. 19, 8-28.

Acquarone, E., Monacelli, F., Borghi, R., Nencioni, A., and Odetti, P. (2019). Resistin: A reappraisal. Mech. Ageing Dev. 178, 46-63. doi: 10.1016/j.mad.2019.01.004

Akhtar Khan, N. (2010). Polyunsaturated fatty acids in the modulation of T-cell signalling. Prostaglandins, Leukot. Essent. Fat. Acids 82, 179-187. doi: 10.1016/j.plefa.2010.02.023

Allen, D. L., Hittel, D. S., and McPherron, A. C. (2011). Expression and function of myostatin in obesity, diabetes, and exercise adaptation. Med. Sci. Sport. Exerc. 43, 1828-1835. doi: 10.1249/MSS.0b013e3182178bb4

Allen, J., Sun, Y., and Woods, J. A. (2015). "Exercise and the Regulation of Inflammatory Responses," in Progress in Molecular Biology and Translational Science (Elsevier Inc.) p. 337-354. doi: 10.1016/bs.pmbts.2015.07.003

Arenas-Ramirez, N., Woytschak, J., and Boyman, O. (2015). Interleukin2: biology, design and application. Trends Immunol. 36, 763-777. doi: 10.1016/j.it.2015.10.003

Bachi, A. L. L., Rios, F. J. O., Vaisberg, P. H. C., Martins, M., Cavalcante de, S.á, M., Victorino, A. B., et al. (2015). Neuro-immuno-endocrine modulation in marathon runners. Neuroimmunomodulation 22, 196-202. doi: 10.1159/000363061

Balkwill, F. (2009). Tumour necrosis factor and cancer. Nat. Rev. Cancer 9, 361-371. doi: 10.1038/nrc2628

Barbalho, S. M., Prado Neto, E. V., De Alvares Goulart, R., Bechara, M. D., Baisi Chagas, E. F., Audi, M., et al. (2020). Myokines: a descriptive review. J. Sports Med. Phys. Fitness 60, 1583-1590. doi: 10.23736/S0022-4707.20.10884-3

Batatinha, H., Tavares-Silva, E., Leite, G. S. F., Resende, A. S., Albuquerque, J. A. T., Arslanian, C., et al. (2020). Probiotic supplementation in marathonists and its impact on lymphocyte population and function after a marathon: a randomized placebo-controlled double-blind study. Sci. Rep. 10, 18777. doi: 10.1038/s41598-020-75464-0

Bekos, C., Zimmermann, M., Unger, L., Janik, S., Mitterbauer, A., Koller, M., et al. (2019). Exercise-induced bronchoconstriction, temperature regulation and the role of heat shock proteins in non-asthmatic recreational marathon and half-marathon runners. Sci. Rep. 9, 4168. doi: 10.1038/s41598-019-39983-9

Benedetti, S., Gemma Nasoni, M., Palma, F., Citarella, R., and Luchetti, F. (2021). Serum changes in sTWEAK and its scavenger receptor sCD163 in ultramarathon athletes running the 24-h race. Cytokine 137, 155315. doi: 10.1016/j.cyto.2020.155315

Bent, R., Moll, L., Grabbe, S., and Bros, M. (2018). Interleukin-1 beta-A friend or foe in malignancies? Int. J. Mol. Sci. 19, 2155. doi: 10.3390/ijms19082155

Bernecker, C., Scherr, J., Schinner, S., Braun, S., Scherbaum, W. A., and Halle, M. (2013). Evidence for an exercise induced increase of TNF- $\alpha$ and IL-6 in marathon runners. Scand. J. Med. Sci. Sports 23, 207-214. doi: 10.1111/j.1600-0838.2011.01372.x

Bjersing, J. L., Erlandsson, M., Bokarewa, M. I., and Mannerkorpi, K. (2013). Exercise and obesity in fibromyalgia: beneficial roles of IGF-1 and resistin? Arthritis Res. Ther. 15, R34. doi: 10.1186/ar4187

Bonsignore, M. R., Morici, G., Santoro, A., Pagano, M., Cascio, L., Bonanno, A., et al. (2002). Circulating hematopoietic progenitor cells in runners. J. Appl. Physiol. 93, 1691-1697. doi: 10.1152/japplphysiol.00376.2002

\section{ACKNOWLEDGMENTS}

We would like to thank the Coordination of the PostGraduation Program of Physical Education, Federal University of Sergipe (UFS), the members of the Group of Studies and Research of Performance, Sport, Health and Paralympic Sports (GEPEPS), and the members of the Running Club of UFS.

Carey, A. L., Steinberg, G. R., Macaulay, S. L., Thomas, W. G., Holmes, A. G., Ramm, G., et al. (2006). Interleukin-6 increases insulin-stimulated glucose disposal in humans and glucose uptake and fatty acid oxidation in vitro via AMP-activated protein kinase. Diabetes 55, 2688-2697. doi: 10.2337/db05-1404

Castell, L. M., Poortmans, J. R., Leclercq, R., Brasseur, M., Duchateau, J., and Newsholme, E. A. (1996). Some aspects of the acute phase response after a marathon race, and the effects of glutamine supplementation. Eur. J. Appl. Physiol. Occup. Physiol. 75, 47-53. doi: 10.1007/s004210050125

Cerqueira, É., Marinho, D. A., Neiva, H. P., and Lourenço, O. (2020). Inflammatory effects of high and moderate intensity exercise-a systematic review. Front. Physiol. 10, 1-14. doi: 10.3389/fphys.2019.01550

Chiu, Y.-H., Hou, S.-K., How, C.-K., Li, L.-H., Kao, W.-F., Yang, C.-C., et al. (2013). Influence of a $100-\mathrm{km}$ ultra-marathon on hepatitis b carrier runners. Int. J. Sports Med. 34, 841-845. doi: 10.1055/s-0032-1331769

Clifford, T., Allerton, D. M., Brown, M. A., Harper, L., Horsburgh, S., Keane, K. M., et al. (2017). Minimal muscle damage after a marathon and no influence of beetroot juice on inflammation and recovery. Appl. Physiol. Nutr. Metab. 42, 263-270. doi: 10.1139/apnm-2016-0525

Conti, G., De Pol, A., Scarpini, E., Vaccina, F., De Riz, M., Baron, P., et al. (2002). Interleukin-1beta and interferon-gamma induce proliferation and apoptosis in cultured Schwann cells. J. Neuroimmunol. 124, 29-35. doi: 10.1016/S0165-5728(02)00003-6

Costello, R., Willems, M. E. T., Myers, S. D., Myers, F., Lewis, N. A., Lee, B. J., et al. (2020). No effect of New Zealand blackcurrant extract on recovery of muscle damage following running a half-marathon. Int. J. Sport Nutr. Exerc. Metab. 30, 287-294. doi: 10.1123/ijsnem.2019-0312

Cox, A. J., Gleeson, M., Pyne, D. B., Saunders, P. U., Callister, R., and Fricker, P. A. (2010). Respiratory symptoms and inflammatory responses to Difflam throatspray intervention in half-marathon runners: A randomised controlled trial. $\mathrm{Br}$. J. Sports Med. 44, 127-133. doi: 10.1136/bjsm.2008.048298

Czajkowska, A., Ambroszkiewicz, J., Mróz, A., Witek, K., Nowicki, D., and Małek, Ł. (2020). The effect of the ultra-marathon run at a distance of 100 kilometers on the concentration of selected adipokines in adult men. Int. J. Environ. Res. Public Health 17, 4289. doi: 10.3390/ijerph17124289

Das, D. K., Graham, Z. A., and Cardozo, C. P. (2020). Myokines in skeletal muscle physiology and metabolism: Recent advances and future perspectives. Acta Physiol. 228, 0-3. doi: 10.1111/apha.13367

de Oliveira dos Santos, A. R., de Oliveira Zanuso, B., Miola, V. F. B., Barbalho, S. M., Santos Bueno, P. C., Flato, U. A. P., et al. (2021). Adipokines, myokines, and hepatokines: crosstalk and metabolic repercussions. Int. J. Mol. Sci. 22, 2639. doi: 10.3390/ijms22052639

Díaz-Castro, J., Guisado, R., Kajarabille, N., García, C., Guisado, I. M., de Teresa, C., et al. (2012). Coenzyme Q10 supplementation ameliorates inflammatory signaling and oxidative stress associated with strenuous exercise. Eur. J. Nutr. 51, 791-799. doi: 10.1007/s00394-011-0257-5

Donnikov, A. E., Shkurnikov, M. Y., Akimov, E. B., Grebenyuk, E. S., Khaustova, S. A., Shahmatova, E. M., et al. (2009). Effect of a six-hour marathon ultrarace on the levels of IL-6, LIF, and SCF. Bull. Exp. Biol. Med. 148, 819-821. doi: 10.1007/s10517-010-0825-3

dos Santos, J., de, M. B., Bachi, A. L. L., Junior, L. A. L., Foster, R., Sierra, A. P. R., et al. (2020). The relationship of IL-8 and IL-10 myokines and performance in male marathon runners presenting exercise-induced bronchoconstriction. Int. J. Environ. Res. Public Health 17, 1-15. doi: 10.3390/ijerph17082622

Drenth, J. P. H., Van Uum, S. H. M., Van Deuren, M., Pesman, G. J., Van der Ven-Jongekrijg, J., and Van der Meer, J. W. (1995). Endurance run increases 
circulating IL-6 and IL-1ra but downregulates ex vivo TNF-alpha and IL-1 beta production. J. Appl. Physiol. 79, 1497-1503. doi: 10.1152/jappl.1995.79.5.1497

Fehrenbach, E., Niess, A. M., Schlotz, E., Passek, F., Dickhuth, H.-H., and Northoff, H. (2000). Transcriptional and translational regulation of heat shock proteins in leukocytes of endurance runners. J. Appl. Physiol. 89, 704-710. doi: 10.1152/jappl.2000.89.2.704

Fernandes, M. S., de, S., Silva, L. de L. de S. e., Kubrusly, M. S., Lima, T. R. L., de, A., et al. (2020). Aerobic exercise training exerts beneficial effects upon oxidative metabolism and non-enzymatic antioxidant defense in the liver of leptin deficiency mice. Front. Endocrinol. (Lausanne). 11, 1-9. doi: $10.3389 /$ fendo.2020.588502

Frydelund-Larsen, L., Penkowa, M., Akerstrom, T., Zankari, A., Nielsen, S., and Pedersen, B. K. (2007). Exercise induces interleukin-8 receptor (CXCR2) expression in human skeletal muscle. Exp. Physiol. 92, 233-240. doi: 10.1113/expphysiol.2006.034769

Gaggini, M., Vassalle, C., Carli, F., Maltinti, M., Sabatino, L., Buzzigoli, E., et al. (2021). Changes in Plasma Bioactive Lipids and Inflammatory Markers during a Half-Marathon in Trained Athletes. Appl. Sci. 11, 4622. doi: 10.3390/app11104622

Gill, S., Hankey, J., Wright, A., Marczak, S., Hemming, K., Allerton, D., et al. (2015a). The impact of a 24-h ultra-marathon on circulatory endotoxin and cytokine profile. Int. J. Sports Med. 36, 688-695. doi: 10.1055/s-0034-1398535

Gill, S. K., Teixeira, A., Rama, L., Prestes, J., Rosado, F., Hankey, J., et al. (2015b). Circulatory endotoxin concentration and cytokine profile in response to exertional-heat stress during a multi-stage ultra-marathon competition. Exerc. Immunol. Rev. 21, 114-28. Available at: http://www.ncbi.nlm.nih.gov/ pubmed/25830597.

Gleeson, M., Bishop, N. C., Stensel, D. J., Lindley, M. R., Mastana, S. S., and Nimmo, M. A. (2011). The anti-inflammatory effects of exercise: mechanisms and implications for the prevention and treatment of disease. Nat. Rev. Immunol. 11, 607-615. doi: 10.1038/nri3041

Glund, S., and Krook, A. (2007). Role of interleukin-6 signalling in glucose and lipid metabolism. Acta Physiol. 192, 37-48. doi: 10.1111/j.1748-1716.2007.01779.x

Gomarasca, M., Banfi, G., and Lombardi, G. (2020). "Myokines: The endocrine coupling of skeletal muscle and bone," in Advances in Clinical Chemistry (Elsevier Inc.) 155-218. doi: 10.1016/bs.acc.2019.07.010

Goussetis, E., Spiropoulos, A., Tsironi, M., Skenderi, K., Margeli, A., Graphakos, S., et al. (2009). Spartathlon, a 246 kilometer foot race: Effects of acute inflammation induced by prolonged exercise on circulating progenitor reparative cells. Blood Cells, Mol. Dis. 42, 294-299. doi: 10.1016/j.bcmd.2009.01.003

Henson, D. A., Nieman, D. C., Pistilli, E. E., Schilling, B., Colacino, A., Utter, A. C., et al. (2004). Influence of carbohydrate and age on lymphocyte function following a marathon. Int. J. Sport Nutr. Exerc. Metab. 14, 308-322. doi: 10.1123/ijsnem.14.3.308

Higgins, C. A., Judge, T. A., and Ferris, G. R. (2003). Influence tactics and work outcomes: a meta-analysis. J. Organ. Behav. 24, 89-106. doi: 10.1002/job.181

Higgins, J. P. T., Altman, D. G., Gotzsche, P. C., Juni, P., Moher, D., Oxman, A. D., et al. (2011). The Cochrane Collaboration's tool for assessing risk of bias in randomised trials. BMJ 343, d5928-d5928. doi: 10.1136/bmj.d5928

Howatson, G., McHugh, M. P., Hill, J. A., Brouner, J., Jewell, A. P., Van Someren, K. A., et al. (2010). Influence of tart cherry juice on indices of recovery following marathon running. Scand. J. Med. Sci. Sports 20, 843-852. doi: 10.1111/j.1600-0838.2009.01005.x

Jamurtas, A. Z., Stavropoulos-Kalinoglou, A., Koutsias, S., Koutedakis, Y., and Fatouros, I. (2015). Adiponectin, resistin, and visfatin in childhood obesity and exercise. Pediatr. Exerc. Sci. 27, 454-462. doi: 10.1123/pes.2014-0072

Järvinen, T. A., Järvinen, M., and Kalimo, H. (2013). Regeneration of injured skeletal muscle after the injury. Muscles. Ligaments Tendons J. 3, 337-345. doi: $10.32098 / \mathrm{mlti} .04 .2013 .16$

Kasprowicz, K., Ratkowski, W., Wołyniec, W., Kaczmarczyk, M., and Witek, K., Zmijewski, P., et al. (2020). The effect of vitamin D3 supplementation on hepcidin, iron, and IL-6 responses after a $100 \mathrm{~km}$ ultra-marathon. Int. J. Environ. Res. Public Health 17, 2962. doi: 10.3390/ijerph170 82962

Kaufmann, C. C., Wegberger, C., Tscharre, M., Haller, P. M., Piackova, E., Vujasin, I., et al. (2021). Effect of marathon and ultra-marathon on inflammation and iron homeostasis. Scand. J. Med. Sci. Sports 31, 542-552. doi: 10.1111/sms.13869

Keller, C., Steensberg, A., Pilegaard, H., Osada, T., Saltin, B., Pedersen, B. K., et al. (2001). Transcriptional activation of the IL-6 gene in human contracting skeletal muscle: influence of muscle glycogen content. FASEB J. 15, 1-15. doi: 10.1096/fj.01-0507fje

Kerschan-Schindl, K., Thalmann, M., Sodeck, G. H., Skenderi, K., Matalas, A. L., Grampp, S., et al. (2009). A 246-km continuous running race causes significant changes in bone metabolism. Bone 45, 1079-1083. doi: 10.1016/j.bone.2009.07.088

Kim, H. J., Lee, Y. H., and Kim, C. K. (2007). Biomarkers of muscle and cartilage damage and inflammation during a $200 \mathrm{~km}$ run. Eur. J. Appl. Physiol. 99, 443-447. doi: 10.1007/s00421-006-0362-y

Knechtle, B., and Nikolaidis, P. T. (2018). Physiology and pathophysiology in ultra-marathon running. Front. Physiol. 9, 634. doi: 10.3389/fphys.2018.00634

Larsen, E. L., Poulsen, H. E., Michaelsen, C., Kjær, L. K., Lyngbæk, M., Andersen, E. S., et al. (2020). Differential time responses in inflammatory and oxidative stress markers after a marathon: An observational study. J. Sports Sci. 38, 2080-2091. doi: 10.1080/02640414.2020.1770918

Leal, L. G., Lopes, M. A., and Batista, M. L. (2018). Physical exercise-induced myokines and muscle-adipose tissue crosstalk: a review of current knowledge and the implications for health and metabolic diseases. Front. Physiol. 9, 1-17. doi: $10.3389 /$ fphys.2018.01307

Li, H.-Y., Hong, X., Cao, Q.-Q., and So, K.-F. (2019). "Adiponectin, exercise and eye diseases," in International Review of Neurobiology (Elsevier Inc.) p. 281-294. doi: 10.1016/bs.irn.2019.07.006

Luna Junior, L. A., de Melo Batista dos Santo, J., Lacerda Bachi, A. L., Foster, R., Slowetzky Amaro, A., Ligeiro de Oliveira, A. P., et al. (2016). Relationship between cytokines and running economy in marathon runners. Open Life Sci. 11, 308-312. doi: 10.1515/biol-2016-0041

Margeli, A., Skenderi, K., Tsironi, M., Hantzi, E., Matalas, A.-L., Vrettou, C., et al. (2005). Dramatic elevations of interleukin- 6 and acute-phase reactants in athletes participating in the ultradistance foot race spartathlon: severe systemic inflammation and lipid and lipoprotein changes in protracted exercise. J. Clin. Endocrinol. Metab. 90, 3914-3918. doi: 10.1210/jc.2004-2346

Mastaloudis, A., Morrow, J. D., Hopkins, D. W., Devaraj, S., and Traber, M. G. (2004). Antioxidant supplementation prevents exercise-induced lipid peroxidation, but not inflammation, in ultramarathon runners. Free Radic. Biol. Med. 36, 1329-1341. doi: 10.1016/j.freeradbiomed.2004.02.069

Miles, M. P., Walker, E. E., Conant, S. B., Hogan, S. P., and Kidd, J. R. (2006). Carbohydrate influences plasma interleukin- 6 but not C-reactive protein or creatine kinase following a $32-\mathrm{km}$ mountain trail race. Int. J. Sport Nutr. Exerc. Metab. 16, 36-46. doi: 10.1123/ijsnem.16.1.36

Moldoveanu, A. I., Shephard, R. J., and Shek, P. N. (2001). The cytokine response to physical activity and training. Sport. Med. 31, 115-144. doi: 10.2165/00007256-200131020-00004

Neidhart, M., Müller-Ladner, U., Frey, W., Bosserhoff, A. K., Colombani, P. C., Frey-Rindova, P., et al. (2000). Increased serum levels of noncollagenous matrix proteins (cartilage oligomeric matrix protein and melanoma inhibitory activity) in marathon runners. Osteoarthr. Cartil. 8, 222-229. doi: 10.1053/joca.1999.0293

Ng, Q. Y., Lee, K. W., Byrne, C., Ho, T. F., and Lim, C. L. (2008). Plasma endotoxin and immune responses during a $21-\mathrm{km}$ road race under a warm and humid environment. Ann. Med. Singapore 37, 307.

Nickel, T., Emslander, I., Sisic, Z., David, R., Schmaderer, C., Marx, N., et al. (2012). Modulation of dendritic cells and toll-like receptors by marathon running. Eur. J. Appl. Physiol. 112, 1699-1708. doi: 10.1007/s00421-011-2140-8

Nieman, D. C., Dumke, C. I., Henson, D. A., McAnulty, S. R., McAnulty, L. S., Lind, R. H., et al. (2003). Immune and Oxidative Changes During and Following the Western States Endurance Run. Int. J. Sports Med. 24, 541-547. doi: $10.1055 / \mathrm{s}-2003-42018$

Nieman, D. C., Dumke, C. L., Henson, D. A., McAnulty, S. R., Gross, S. J., and Lind, R. H. (2005). Muscle damage is linked to cytokine changes following a $160-\mathrm{km}$ race. Brain. Behav. Immun. 19, 398-403. doi: 10.1016/j.bbi.2005.03.008

Nieman, D. C., Henson, D. A., Davis, J. M., Dumke, C. L., Gross, S. J., Jenkins, D. P., et al. (2007). Quercetin Ingestion Does Not Alter Cytokine Changes in Athletes Competing in the Western States Endurance Run. J. Interf. Cytokine Res. 27, 1003-1012. doi: 10.1089/jir.2007.0050 
Nieman, D. C., Henson, D. A., Dumke, C. L., Oley, K., McAnulty, S. R., Davis, J. M., et al. (2006). Ibuprofen use, endotoxemia, inflammation, and plasma cytokines during ultramarathon competition. Brain. Behav. Immun. 20, 578-584. doi: 10.1016/j.bbi.2006.02.001

Nieman, D. C., Henson, D. A., McAnulty, S. R., McAnulty, L., Swick, N. S., Utter, A. C., et al. (2002). Influence of vitamin C supplementation on oxidative and immune changes after an ultramarathon. J. Appl. Physiol. 92, 1970-1977. doi: 10.1152/japplphysiol.00961.2001

Nieman, D. C., Henson, D. A., Smith, L. L., Utter, A. C., Vinci, D. M., Davis, J. M., et al. (2001). Cytokine changes after a marathon race. J. Appl. Physiol. 91, 109-114. doi: 10.1152/jappl.2001.91.1.109

Niemelä, M., Kangastupa, P., Niemel,ä, O., Bloigu, R., and Juvonen, T. (2016). Acute changes in inflammatory biomarker levels in recreational runners participating in a marathon or half-marathon. Sport. Med. - Open 2, 21. doi: 10.1186/s40798-016-0045-0

Niess, A. M., Passek, F., Lorenz, I., Schneider, E. M., Dickhuth, H.-H., Northoff, H., et al. (1999). Expression of the antioxidant stress protein heme oxygenase-1 (HO-1) in human leukocytes. Free Radic. Biol. Med. 26, 184-192. doi: 10.1016/S0891-5849(98)00192-0

Ostrowski, K., Rohde, T., Asp, S., Schjerling, P., and Pedersen, B. K. (1999). Proand anti-inflammatory cytokine balance in strenuous exercise in humans. J. Physiol. 515, 287-291. doi: 10.1111/j.1469-7793.1999.287ad.x

Ostrowski, K., Rohde, T., Zacho, M., Asp, S., and Pedersen, B. K. (1998). Evidence that interleukin-6 is produced in human skeletal muscle during prolonged running. J. Physiol. 508, 949-953. doi: 10.1111/j.1469-7793.1998.949bp.x

Ostrowski, K., Schjerling, P., and Pedersen, B. K. (2000). Physical activity and plasma interleukin-6 in humans - effect of intensity of exercise. Eur. J. Appl. Physiol. 83, 512-515. doi: 10.1007/s004210000312

Page, M. J., McKenzie, J. E., Bossuyt, P. M., Boutron, I., Hoffmann, T. C., Mulrow, C. D., et al. (2021). The PRISMA 2020 statement: an updated guideline for reporting systematic reviews. BMJ 372, n71. doi: 10.1136/bmj.n71

Papassotiriou, I., Alexiou, V. G., Tsironi, M., Skenderi, K., Spanos, A., and Falagas, M. E. (2008). Severe aseptic inflammation caused by long distance running $(246 \mathrm{~km})$ does not increase procalcitonin. Eur. J. Clin. Invest. 38, 276-279. doi: 10.1111/j.1365-2362.2008.01935.x

Passos, B. N., Lima, M. C., Sierra, A. P. R., Oliveira, R. A., Maciel, J. F. S., Manoel, R., et al. (2019). Association of Daily Dietary Intake and Inflammation Induced by Marathon Race. Mediators Inflamm. 2019, 1-8. doi: 10.1155/2019/1537274

Pedersen, B. K. (2011). Muscles and their myokines. J. Exp. Biol. 214, 337-346. doi: $10.1242 /$ jeb. 048074

Pedersen, B. K. (2016). "Myokines and Metabolism," in Metabolic Syndrome (Cham: Springer International Publishing) p. 541-554. doi: 10.1007/978-3-319-11251-0_31

Pedersen, B. K. (2017). Anti-inflammatory effects of exercise: role in diabetes and cardiovascular disease. Eur. J. Clin. Invest. 47, 600-611. doi: 10.1111/eci.12781

Pedersen, B. K. (2019). Physical activity and muscle-brain crosstalk. Nat. Rev. Endocrinol. 15, 383-392. doi: 10.1038/s41574-019-0174-x

Pedersen, B. K., and Febbraio, M. A. (2008). Muscle as an endocrine organ: focus on muscle-derived interleukin-6. Physiol. Rev. 88, 1379-1406. doi: 10.1152/physrev.90100.2007

Peters, E. M., Anderson, R., Nieman, D. C., Fickl, H., and Jogessar, V. (2001). Vitamin C supplementation attenuates the increases in circulating cortisol, adrenaline and anti-inflammatory polypeptides following ultramarathon running. Int. J. Sports Med. 22, 537-543. doi: 10.1055/s-2001-17610

Petersen, A. M. W., and Pedersen, B. K. (2005). The anti-inflammatory effect of exercise. J. Appl. Physiol. 98, 1154-1162. doi: 10.1152/japplphysiol.00164.2004

Pistilli, E. E., Nieman, D. C., Henson, D. A., Kaminsky, D. E., Utter, A. C., Vinci, D. M., et al. (2002). Influence of age on immune changes in runners after a marathon. J. Aging Phys. Act. 10, 432-442. doi: 10.1123/japa.10.4.432

Pngwing. (2021). https://www.pngwing.com/pt/free-png-blxjt/download (accessed December 09, 2021).

Pugh, J. N., Sparks, A. S., Doran, D. A., Fleming, S. C., Langan-Evans, C., Kirk, B., et al. (2019). Four weeks of probiotic supplementation reduces GI symptoms during a marathon race. Eur. J. Appl. Physiol. 119, 1491-1501. doi: 10.1007/s00421-019-04136-3

Reihmane, D., Jurka, A., Tretjakovs, P., and Dela, F. (2013). Increase in IL-6, TNF$\alpha$, and MMP-9, but not sICAM-1, concentrations depends on exercise duration. Eur. J. Appl. Physiol. 113, 851-858. doi: 10.1007/s00421-012-2491-9
Roupas, N., Mamali, I., Maragkos, S., Leonidou, L., Armeni, A., Markantes, G., et al. (2013). The effect of prolonged aerobic exercise on serum adipokine levels during an ultra-marathon endurance race. Hormones 12, 275-282. doi: 10.14310/horm.2002.1411

Sansoni, V., Vernillo, G., Perego, S., Barbuti, A., Merati, G., Schena, F., et al. (2017). Bone turnover response is linked to both acute and established metabolic changes in ultra-marathon runners. Endocrine 56, 196-204. doi: 10.1007/s12020-016-1012-8

Santos, V. C., Levada-Pires, A. C., Alves, S. R., Pithon-Curi, T. C., Curi, R and Cury-Boaventura, M. F. (2013a). Changes in lymphocyte and neutrophil function induced by a marathon race. Cell Biochem. Funct. 31, 237-243. doi: $10.1002 / \mathrm{cbf} .2877$

Santos, V. C., Levada-Pires, A. C., Alves, S. R., Pithon-Curi, T. C., Curi, R., and Cury-Boaventura, M. F. (2013b). Effects of DHA-rich fish oil supplementation on lymphocyte function before and after a marathon race. Int. J. Sport Nutr. Exerc. Metab. 23, 161-169. doi: 10.1123/ijsnem.23.2.161

Santos, V. C., Sierra, A. P. R., Oliveira, R., Caçula, K. G., Momesso, C. M., Sato, F. T., et al. (2016). Marathon race affects neutrophil surface molecules: role of inflammatory mediators. PLoS ONE. 11, e0166687. doi: 10.1371/journal.pone.0166687

Saraiva, M., and O'Garra, A. (2010). The regulation of IL-10 production by immune cells. Nat. Rev. Immunol. 10, 170-181. doi: 10.1038/nri2711

Scherr, J., Braun, S., Schuster, T., Hartmann, C., Moehlenkamp, S., Wolfarth, B., et al. (2011). 72-h Kinetics of high-sensitive troponin $\mathrm{T}$ and inflammatory markers after marathon. Med. Sci. Sport. Exerc. 43, 1819-1827. doi: 10.1249/MSS.0b013e31821b12eb

Scherr, J., Nieman, D. C., Schuster, T., Habermann, J., Rank, M., Braun, S., et al. (2012). Nonalcoholic beer reduces inflammation and incidence of respiratory tract illness. Med. Sci. Sports Exerc. 44, 18-26. doi: 10.1249/MSS.0b013e3182250dda

Shanely, R. A., Nieman, D. C., Zwetsloot, K. A., Knab, A. M., Imagita, H., Luo, B., et al. (2014). Evaluation of Rhodiola rosea supplementation on skeletal muscle damage and inflammation in runners following a competitive marathon. Brain. Behav. Immun. 39, 204-210. doi: 10.1016/j.bbi.2013. 09.005

Shin, Y. O., and Lee, J. B. (2013). Leukocyte chemotactic cytokine and leukocyte subset responses during ultra-marathon running. Cytokine. 61, 364-369. doi: 10.1016/j.cyto.2012.11.019

Shoghi, K. I., Gropler, R. J., Sharp, T., Herrero, P., Fettig, N., Su, Y., et al. (2008). Time course of alterations in myocardial glucose utilization in the zucker diabetic fatty rat with correlation to gene expression of glucose transporters: a small-animal PET investigation. J. Nucl. Med. 49, 1320-1327. doi: 10.2967/jnumed.108.051672

Siegel, A. J., Verbalis, J. G., Clement, S., Mendelson, J. H., Mello, N. K., Adner, M., et al. (2007). Hyponatremia in marathon runners due to inappropriate arginine vasopressin secretion. Am. J. Med. 120 461.e11-461.e17. doi: 10.1016/j.amjmed.2006.10.027

Sierra, A. P., Oliveira-Junior, M. C., Almeida, F. M., Benetti, M., Oliveira, R., Felix, S. N., et al. (2019a). Impairment on cardiopulmonary function after marathon: role of exhaled nitric oxide. Oxid. Med. Cell. Longev. 2019. doi: $10.1155 / 2019 / 5134360$

Sierra, A. P. R., Lima, G. H. O., da Silva, E. D., Maciel, J. F., de, S., Benetti, M. P., et al. (2019b). Angiotensin-converting enzyme related-polymorphisms on inflammation, muscle and myocardial damage after a marathon race. Front. Genet. 10, 1-12. doi: 10.3389/fgene.2019.00984

Skinner, S., Nader, E., Stauffer, E., Robert, M., Boisson, C., Cibiel, A., et al. (2021). Differential impacts of trail and ultra-trail running on cytokine profiles: An observational study. Clin. Hemorheol. Microcirc. 78, 301-310. doi: $10.3233 / \mathrm{CH}-211121$

Sliwicka, E., Ciso,ń, T., Pilaczyńska-Szcześniak, Ł., Ziemba, A., and StraburzyńskaLupa, A. (2021). Effects of marathon race on selected myokines and sclerostin in middle-aged male amateur runners. Sci. Rep. 11, 1-9. doi: 10.1038/s41598-021-82288-z

Smith, K. A., Kisiolek, J. N., Willingham, B. D., Morrissey, M. C., Leyh, S. M., Saracino, P. G., et al. (2020). Ultra-endurance triathlon performance and markers of whole-body and gut-specific inflammation. Eur. J. Appl. Physiol. 120, 349-357. doi: 10.1007/s00421-01904279-3 
Smith, L. L. (2000). Cytokine hypothesis of overtraining: a physiological adaptation to excessive stress? Med. Sci. Sport. Exerc. 32, 317. doi: 10.1097/00005768-200002000-00011

Starkie, R. L., Rolland, J., Angus, D. J., Anderson, M. J., and Febbraio, M. A. (2001). Circulating monocytes are not the source of elevations in plasma IL- 6 and TNF- $\alpha$ levels after prolonged running. Am. J. Physiol. Physiol. 280, C769-C774. doi: 10.1152/ajpcell.2001.280.4.C769

Steensberg, A., Febbraio, M. A., Osada, T., Schjerling, P., Hall, G., Saltin, B., et al. (2001). Interleukin-6 production in contracting human skeletal muscle is influenced by pre-exercise muscle glycogen content. J. Physiol. 537, 633-639. doi: 10.1111/j.1469-7793.2001.00633.x

Suzuki, K., Nakaji, S., Yamada, M., Liu, Q., Kurakake, S., Okamura, N., et al. (2003). Impact of a competitive marathon race on systemic cytokine and neutrophil responses. Med. Sci. Sports Exerc. 35, 348-355. doi: 10.1249/01.MSS.0000048861.57899.04

Suzuki, K., Yamada, M., Kurakake, S., Okamura, N., Yamaya, K., Liu, Q., et al. (2000). Circulating cytokines and hormones with immunosuppressive but neutrophil-priming potentials rise after endurance exercise in humans. Eur. J. Appl. Physiol. 81, 281-287. doi: 10.1007/s004210050044

Tanner, E. A., Gary, M. A., Davis, A. A., Michalik, S., and McFarlin, B. K. (2021). Alterations in systemic inflammatory response following a half-marathon race with a combined curcumin and pomegranate supplement: a feasibility study. J. Diet. Suppl. 18, 461-477. doi: 10.1080/19390211.2020.1786206

Tavares-Silva, E., Caris, A. V., Santos, S. A., Ravacci, G. R., and ThomatieliSantos, R. V. (2021). Effect of multi-strain probiotic supplementation on URTI symptoms and cytokine production by monocytes after a marathon race: a randomized, double-blind, placebo study. Nutrients 13, 1478. doi: $10.3390 /$ nu13051478

Terra, R., Silva, S. A. G., da, Pinto, V. S., and Dutra, P. M. L. (2012). Efeito do exercício no sistema imune: resposta, adaptação e sinalização celular. Rev. Bras. Med. do Esporte 18, 208-214. doi: 10.1590/S1517-86922012000300015

Toft, A. D., Thorn, M., Ostrowski, K., Asp, S., Møller, K., Iversen, S., et al. (2000). $\mathrm{N}-3$ polyunsaturated fatty acids do not affect cytokine response to strenuous exercise. J. Appl. Physiol. 89, 2401-2406. doi: 10.1152/jappl.2000.89.6.2401

Turcotte, L. P., and Fisher, J. S. (2008). Skeletal muscle insulin resistance: roles of fatty acid metabolism and exercise. Phys. Ther. 88, 1279-1296. doi: $10.2522 /$ ptj. 20080018

Uchakin, P. N., Gotovtseva, E. P., and Stray-Gundersen, J. (2003). Immune and neuroendocrine alterations in marathon runners. J. Appl. Res. 3, 483-494.

Uchida, M., Oyanagi, E., Kawanishi, N., Iemitsu, M., Miyachi, M., Kremenik, M. J., et al. (2014). Exhaustive exercise increases the TNF- $\alpha$ production in response to flagellin via the upregulation of toll-like receptor 5 in the large intestine in mice. Immunol. Lett. 158, 151-158. doi: 10.1016/j.imlet.2013.12.021

Vaisberg, M., Bachi, A. L. L., Latrilha, C., Dioguardi, G. S., Bydlowski, S. P., and Maranhão, R. C. (2012). Lipid transfer to HDL is higher in marathon runners than in sedentary subjects, but is acutely inhibited during the run. Lipids 47 , 679-686. doi: 10.1007/s11745-012-3685-y

Vaisberg, M., Suguri, V. M., Gregorio, L. C., Lopes, J. D., and Bachi, A. L. L. (2013). Cytokine kinetics in nasal mucosa and sera: new insights in understanding upper-airway disease of marathon runners. Exerc. Immunol. Rev. 19, 49-59. Available at: http://www.ncbi.nlm.nih.gov/pubmed/23977719.

Vuolteenaho, K., Leppänen, T., Kekkonen, R., Korpela, R., and Moilanen, E. (2014). Running a marathon induces changes in adipokine levels and in markers of cartilage degradation - novel role for resistin. PLOS ONE. 9, e110481. doi: 10.1371/journal.pone.0110481

Weigert, C., Hennige, A. M., Brodbeck, K., Häring, H. U., and Schleicher, E. D. (2005). Interleukin-6 acts as insulin sensitizer on glycogen synthesis in human skeletal muscle cells by phosphorylation of Ser 473 of Akt. Am. J. Physiol. Metab. 289, E251-E257. doi: 10.1152/ajpendo.00448.2004

Weinstock, C., KöNig, D., Harnischmacher, R., Keul, J., Berg, A., and Northoff, H. (1997). Effect of exhaustive exercise stress on the cytokine response. Med. ¿amp Sci. Sport. \&amp Exerc. 29, 345-354. doi: 10.1097/00005768-19970300000009

Wilhelm, M., Zueger, T., De Marchi, S., Rimoldi, S. F., Brugger, N., Steiner, R., et al. (2014). Inflammation and atrial remodeling after a mountain marathon. Scand. J. Med. Sci. Sports 24, 519-525. doi: 10.1111/sms.12030

Wołyniec, W., Ratkowski, W., Kasprowicz, K., Małgorzewicz, S., Aleksandrowicz, E., Zdrojewski, T., et al. (2020). Factors influencing post-exercise proteinuria after marathon and ultramarathon races. Biol. Sport 37, 33-40. doi: 10.5114/biolsport.2020.89939

Wu, R., Li, N., Zhao, X., Ding, T., Xue, H., Gao, C., et al. (2020). Lowdose Interleukin-2: Biology and therapeutic prospects in rheumatoid arthritis. Autoimmun. Rev. 19, 102645. doi: 10.1016/j.autrev.2020.102645

Yargic, M. P., Torgutalp, S., Akin, S., Babayeva, N., Torgutalp, M., and Demirel, H. A. (2019). Acute long-distance trail running increases serum IL-6, IL-15, and Hsp72 levels. Appl. Physiol. Nutr. Metab. 44, 627-631. doi: 10.1139/apnm-2018-0520

Yetgin, M. K., Agopyan, A., Kucukler, F. K., Gedikbasi, A., Yetgin, S., Kayapinar, F. C., et al. (2018). The influence of physical training modalities on basal metabolic rate and leptin on obese adolescent boys. J. Pak. Med. Assoc. 68, 929-931.

Zaccaria, M., Ermolao, A., Roi, G. S., Englaro, P., Tegon, G., and Varnier, M. (2002). Leptin reduction after endurance races differing in duration and energy expenditure. Eur. J. Appl. Physiol. 87, 108-111. doi: 10.1007/s00421-0020606-4

Zaldivar, F., Wang-Rodriguez, J., Nemet, D., Schwindt, C., Galassetti, P., Mills, P. J., et al. (2006). Constitutive pro- and anti-inflammatory cytokine and growth factor response to exercise in leukocytes. J. Appl. Physiol. 100, 1124-1133. doi: 10.1152/japplphysiol.00562.2005

Zhang, Y., and Chua, S. (2017). "Leptin Function and Regulation," in Comprehensive Physiology (Wiley) 351-369. doi: 10.1002/cphy.c160041

Zimmer, P., Baumann, F. T., Bloch, W., Zopf, E. M., Schulz, S., Latsch, J., et al. (2016). Impact of a half marathon on cellular immune system, proinflammatory cytokine levels, and recovery behavior of breast cancer patients in the aftercare compared to healthy controls. Eur. J. Haematol. 96, 152-159. doi: 10.1111/ejh.12561

Conflict of Interest: The authors declare that the research was conducted in the absence of any commercial or financial relationships that could be construed as a potential conflict of interest.

Publisher's Note: All claims expressed in this article are solely those of the authors and do not necessarily represent those of their affiliated organizations, or those of the publisher, the editors and the reviewers. Any product that may be evaluated in this article, or claim that may be made by its manufacturer, is not guaranteed or endorsed by the publisher.

Copyright (c) 2022 Alves, Silva, Pereira, Pereira, de Sousa Fernandes, Santos, Oliveira, Vieira-Souza, Aidar and de Souza. This is an open-access article distributed under the terms of the Creative Commons Attribution License (CC BY). The use, distribution or reproduction in other forums is permitted, provided the original author(s) and the copyright owner(s) are credited and that the original publication in this journal is cited, in accordance with accepted academic practice. No use, distribution or reproduction is permitted which does not comply with these terms. 